\title{
Investments in Managerial Human Capital: Explanations from Prospect and Regulatory Focus Theories
}

\author{
Yuxi Zhao \\ Economics Division, Nottingham Business School, $8^{\text {th }}$ Floor Newton Building, Nottingham \\ Trent University, 50 Shakespeare Street, Nottingham, NG1 4FQ. UK \\ Email: Zhao, yuxi.zhao022012@my.ntu.ac.uk
}

\section{Piers Thompson}

Economics Division, Nottingham Business School, $8^{\text {th }}$ Floor Newton Building, Nottingham Trent University, 50 Shakespeare Street, Nottingham, NG1 4FQ. UK

Email: piers.thompson@ntu.ac.uk

\section{Abstract}

It is recognised that small and medium sized enterprises (SMEs) have relatively low levels of management and employee training. In part, this reflects training being a risky investment, with opportunity costs. This article utilises prospect and regulatory focus theory to provide greater insight into which business owners/managers are more likely to make investments in managerial human capital. The study utilises the Longitudinal Small Business Survey (LSBS) and explores how regulatory focus affects training choices and whether experiencing a gain or loss plays a role. We find that those with a promotion focus and experiencing a gain are more likely to invest in managerial training. There is some evidence of prevention focused business owners/managers being more likely to invest when a loss has been suffered. The results are of interest to policy makers seeking to increase investment in training and for those providing such initiatives in that developing a promotion focus should encourage greater engagement.

This is a post-print version of an article published in the International Small Business Journal:

Zhao, Y. and Thompson, P. (2019) 'Investments in Managerial Human Capital: Explanations from Prospect and Regulatory Focus Theories', International Small Business Journal. doi: $10.1177 / 0266242619828264$

which can be found in its final form at:

http://dx.doi.org/10.1177/0266242619828264 
Investments in Managerial Human Capital: Explanations from Prospect and Regulatory Focus

Theories

\section{Abstract}

It is recognised that small and medium sized enterprises (SMEs) have relatively low levels of management and employee training. In part, this reflects training being a risky investment, with opportunity costs. This article utilises prospect and regulatory focus theory to provide greater insight into which business owners/managers are more likely to make investments in managerial human capital. The study utilises the Longitudinal Small Business Survey (LSBS) and explores how regulatory focus affects training choices and whether experiencing a gain or loss plays a role. We find that those with a promotion focus and experiencing a gain are more likely to invest in managerial training. There is some evidence of prevention focused business owners/managers being more likely to invest when a loss has been suffered. The results are of interest to policy makers seeking to increase investment in training and for those providing such initiatives in that developing a promotion focus should encourage greater engagement.

Keywords: Managerial Training; Human Capital; Regulatory Focus Theory; Prospect Theory; Risky Decision Making

1. Introduction

Governments seeking to support employment, growth and innovation frequently turn to small and medium sized enterprises (SMs) (Enterprise Research Centre et al., 2015), but in order to make these contributions it is argued that SMEs must have access to appropriate human capital (Mehra et al., 2014; Clifton et al., 2015). Research has found that SMEs under-invest in the skills and training compared to their larger counterparts (Hoque and Bacon, 2008; Castany, 2010). While the availability of resources is one explanation as to which SMEs might invest in human capital (Padachi 
and Bhiwajee, 2016; Sung and Choi, 2016), it is not clear that this is the only explanation, given the variety of firms that make such investments (Kotey and Folker, 2007). Theoretical understanding, including potential psychological explanations in terms of which owners/managers invest in their own and management skills concentrates on a narrow range of conceptual perspectives that should be broadened (Nolan and Garavan, 2016a).

This article draws upon two theories from psychology, prospect theory (Kahneman and Tverrsky, 1979; Tversky and Kahneman, 1992), and regulatory focus theory (Higgins, 1997), to ascertain whether these can provide any further insight. In the case of the former, context in terms of whether owners/managers consider they have experienced a gain or loss previously will be important in terms of making risky investments. Regulatory focus theory however, suggests that different systems are concerned with activities associated with achievement and security, the promotion and prevention systems respectively. The article examines whether greater promotion, or prevention, focus makes owners/managers more or less likely to invest in managerial human capital. The two theories are also combined as different types of individual may react differently having been previously exposed to a gain or loss.

Policy makers must exhibit caution in intervening in this debate; given that there is mixed evidence whether managerial training actually improves SME performance, SME owners may be making a rational choice to withhold investment (Bager et al., 2015). Similarly, policymakers are unlikely to be best placed to design management training (Georgiadis and Pitelis, 2016), potentially resulting in provision being too generic or inappropriate for SME needs (Jones et al., 2013). However, when contrasted with larger businesses, SME investments in human capital are suboptimal (Garavan et al., 2016). Understanding why and when firms seek training allows providers to better match their initiatives to SME owner needs so generating more relevant incentives to take up training. It will also help business advisors to understand why owners may be more reticent to invest in such training. Rather than providing financial incentives, the worth of such investments can be framed 
differently to overcome the psychological burdens, or help owners to better understand their own decisions and make more informed judgements.

To examine these relationships the 2015 and 2016 waves of data from the Longitudinal Small Business Survey (LSBS) are used to determine how situations present in 2015 influence the decision to invest in managerial human capital in 2016 for UK SMEs, partially alleviating issues of reverse causality. The study focuses on investments in managerial training as this is likely to have the greater influence on SME performance. Given the limited resources of SMEs both formal off the job training and informal on the job training in 2016 are compared. Whether a gain or loss has been experienced is captured through changes in turnover in 2015. Promotion and prevention focus are captured by goals set in 2015. To control for other influences the decision to invest in managerial human capital in 2016 is examined using binary logistic regression analysis. To account for the possible combined impact of the two theoretical influences interaction terms are included.

The remainder of the article is structured as follows. In the next section we outline theories and evidence from empirical studies of SME human capital investment decisions. The literature review then goes on to introduce prospect theory and regulatory focus theory and illustrate how these may explain the choice to provide training for managers. Hypotheses are developed throughout the section. Section 3 then introduces the LSBS data, measures created and analysis approach used to test the hypotheses. Section 4 outlines the results of the regression analysis and Section 5 summarises and draws conclusions for theory, policy and practice.

2. Investments in Managerial Human Capital and Behavioural Theories

This article concentrates on the relationship between growth, as contained within the psychological makeup of SME owners/managers, that which is actually realised, and decisions about managerial training provision. The next subsection will examine the more traditional theoretical and empirical work on this relationship, whilst subsections 2.2 and 2.3 introduce prospect theory (Kahneman and 
Tversky, 1979; Tversky and Kehneman, 1992) and regulatory focus theory (Higgins, 1997) respectively.

\subsection{SME Human Capital Investment Decisions and the Impact of Growth}

The human capital of SME owners and their employees is important not only for firm success (Sheehan, 2013), but that of the wider population through increased productivity and demand for more sophisticated goods (Millán et al., 2014). Given that a majority of firms in the UK are SMEs, Enterprise Research Centre et al. (2015) highlight how boosting SME productivity growth should significantly affect the UK's overall productivity; as such, training forms a critical part of this argument (Antonioli et al., 2010; Onkelinx et al., 2016). Similarly, Clifton et al. (2015) note how managerial training may be particularly important in managing innovation in SMEs which might otherwise disrupt other activities (Christensen and Raynor, 2003; Heimonen, 2012). This might be expected to increase the owners desire to engage in training, but actual investments are low. Westhead and Storey (1997) suggest that there are two explanations for this 'market forces' and 'ignorance'. The market forces argument relates to demand and supply for training. On the demand side, many business owners feel that training will have no or limited impact on the performance of staff and therefore, have a reluctance to pay for such investments (Panagiotakopoulos, 2011; Jones et al. 2013). Studies examining this link between performance and managerial training find mixed results (Nolan and Garavan, 2016a). In part, the lack of evidence linking training to performance may reflect limited attempts to measure the impact of training by business owners (Coetzer et al., 2012). Understandably, the chief concern for owners is in terms of benefits enjoyed by the firm rather than the employees (Bai et al., 2017). SMEs should not ignore that particular types of training provision can aid SMEs in achieving a favourable position to attract, maintain and motivate high quality employees who have effective transferable skills (Peters and Naicker, 2013; Beynon et al., 2015). However, the risk is that skilled employees are 'poached' by competitors and so, investments in human capital will be lost (Padachi and Bhiwajee, 2016), particularly to larger competitors (Barrett, 
2015). This means business owners have a fear that the investment cost of training would be greater than the return given the loss of trained staff (Panagiotakopoulos, 2011). Thus, we argue that owner decisions will be driven by psychological factors as much as economic rationale; on the supply side, the varied requirements of SMEs limit the potential to cost effectively provide training programmes.

Ignorance arguments relate to a lack of appreciation of the benefits of investing in human capital and more formalised human resource development (Walker et al., 2007). Empirically, there is evidence that larger firms are more likely to provide formal training to their employees (Wapshott and Mallett, 2015; Almeida and Aterido, 2015). This has been attributed to the culture of SMEs, limited awareness of both the available provision and lack of investment funding (van den Berg, 2018). Informality in SME managerial action is a notable tendency, deriving from spatial and social proximity between owners, managers and employees (Marlow et al., 2010). Frequently, only the owner, or one general manager, is responsible for overseeing generic management. This makes them powerful with regard to the approach to learning adopted within the firm, but within a powerful social dynamic with employees (Higgins et al., 2013). A reluctance to delegate authority to specialists results in a lack of professional and well-organised human resource policy and practice (Forth et al., 2006; Cardon and Valentin, 2018). In combination this results in SME owner-managers and employees relying heavily on informal, on-the-job, experiential workplace approaches and socialisation to develop capabilities (Perry et al., 2010; Coetzer et al., 2012; Higgins et al., 2013). Although, it is suggested such informal managerial training has less impact on firm performance, compared to formal provision, (Jayawarna et al., 2007), informality helps to ensure that tailored training matches the needs of the SMEs to provide a competitive advantage (Marlow et al., 2010; Martin et al. 2013; Nolan and Garavan, 2016a, 2016b). External forces however, may operate through regulation (Barrett, 2015) and customer requirements where larger customers push investments towards more formalised training (Macpherson and Jayawarna, 2007). 
The economic success of SMEs may have a critical psychological impact on decisions to invest in managerial human capital; however, given the limited resources of SMEs it could have a more direct relationship. Growth may provide the resources in order to invest (Sung and Choi, 2016; Padachi and Bhiwajee, 2016), and the need for individuals to take on specialised roles requiring training (Castany, 2010). However, in periods of growth focus may be on meeting the demand, with leadership and managerial training seen as a distraction and having a high opportunity cost (Cardon and Valentin, 2018; Garavan et al., 2016).

Evidence indicates that traditionally, SME investments in human capital have been in part influenced by the resources available. As such, those firms that are growing are more likely to have both the need for, and the resources to invest in, human capital. This leads to the first hypothesis:

H1: Those SMEs that have experienced a gain in terms of turnover increases will be more likely to invest in managerial human capital.

\subsection{Prospect Theory and Risky Investments in Managerial Human Capital}

Economic research based upon risky or uncertain decisions draws upon expected value or expected utility theory (Wilkinson and Klaes, 2018). This assumes that individuals calculate the weighted average outcome based on the probabilities of each outcome, and select the option which on average yields the highest payoff. Risk aversion can be incorporated by allowing for a concave utility function. From the psychology literature prospect theory provides an alternative (Kahneman and Tversky, 1979; Tversky and Kahneman, 1992). Kahneman and Tversky (1979) outline how decisions may involve two phases, editing and evaluation. The editing phase uses heuristics to simplify and frame the options, putting them in a more appropriate form for comparison. The second phase is an evaluation phase to examine options in more detail. On the surface a similar approach is used to 
expected utility theory, as the option with the highest expected value is chosen. This expected value is based again, on a weighted average:

$E V=v\left(x_{1}\right) \pi\left(p_{1}\right)+\cdots+v\left(x_{n}\right) \pi\left(p_{n}\right)$

However, unlike expected utility theory, this is based on a set of decision weights $(\pi)$, which allow for over or underweighting of the true probabilities $(p)$. As outlined in equation (2) below and depicted visually in Figure 1, rather than use the concave utility function, the value function $(v)$ provides a level of 'utility' from each potential outcome $(x)$, but accounts for a number of psychological factors: reference points; diminishing sensitivity to gains and losses; and loss aversion:

$v(x)=\begin{array}{cll}(x-r)^{\alpha} & \text { if } & x \geq r \\ -\lambda(r-x)^{\beta} & \text { if } & x<r\end{array}$

Outcomes are not compared to zero, but to a reference point $(r)$, which could be based on the status quo (Kahneman and Tversky, 1979), an aspiration level (Tversky and Kahneman, 1991), or the observations from the past (Baucells et al., 2011). Cyert and March (1963) state that goal dimensions refer to what is important to the organisation, and aspiration levels relate to the target performance for a particular goal. Blettner et al. (2015) suggest that the aspiration levels are based on reference points from a weighted function of the prior goals, prior performance and past performance of reference groups (Cyert and March, 1963; Fiegenbaum et al., 1996). Combining these, Kőszegi and Rabin $(2006,2007,2009)$ argue that reference points are expectations held in the recent past about outcomes, which allow the decision-maker to evaluate choices pertaining to changes in wealth (Hoffmann et al., 2013). Aspirations may be more important normally, but when in financial trouble the performance of competitors comes to the fore (Blettner et al., 2015). Barberis (2013) suggests that the relatively limited application of prospect theory in economic analysis reflects the difficulty in establishing reference points to determine what constitutes a gain or loss.

Whether an outcome is perceived to be above or below the reference point is important as gains 
and losses are treated differently. Evidence from neuroscience suggests that losses generate more hurt than the benefits of equivalent gains (Gehring and Willoughby, 2002). In equation (2) above this is reflected in the term $\lambda$, which is assumed to take a value greater than 1 reflecting the degree of loss aversion. Both gains $(0<\alpha<1)$ and losses $(0<\beta<1)$ also display diminishing marginal sensitivity, whereby further gains (losses) result in smaller increases (decreases) in value than the previous gain (loss). This different treatment of gains and losses and choices once a gain or loss has been experienced may be pertinent for human capital investment decisions as Patton and Marlow (2002) argue SMEs follow a short-term reactive approach due to the external uncertainty they face along with their vulnerability.

With loss aversion present, a company operating at its reference point could invest in human capital, but depending on the success of the training may suffer a loss of $-\mathrm{X}$ or a gain of $\mathrm{X}$ in Figure 1 . If each is equally likely the owner will choose to avoid investing in management human capital as $|v(-X)|>$ $v(\mathrm{X})$. This means that with loss aversion present the potential gains from investing in management training must be much greater than the losses, or the chances of success much higher.

\section{PLEASE INSERT FIGURE 1 ABOUT HERE}

The characteristic of diminishing marginal sensitivity can influence the decisions to invest in human capital differently if a gain or loss has previously been experienced. If a SME has already experienced a loss and is currently at $-\mathrm{X}$ in Figure 1 , it might have the opportunity to invest in management training and if successful may return to the reference point, but if unsuccessful the losses might be doubled to $-2 X$. Doubling the loss does not double the negative value experienced. This makes any investment in management training with the potential to remove an existing loss more attractive. This would fit with the reactive investments in managerial human capital made when problems threaten business performance (Patton and Marlow, 2002). When a gain ( $X$ ) has been experienced the opportunity to double this gain by investing in training, will only increase the value achieved by a relatively small amount $(v(2 \mathrm{X})-v(\mathrm{X}))$. The danger of losing the value already held from the previous 
gain $(v(X))$ will make it unattractive. Prospect theory implies that investments in managerial human capital will be more likely when businesses have had a previous negative outcome:

$\mathrm{H} 2$ : Business owners/managers will be more likely to invest in managerial human capital where they have previously experienced a loss.

This would run contrary to the findings of previous studies noted above that have highlighted the need for resources making more successful SMEs more likely to invest in human capital (Rabie et al., 2016; Sung and Choi, 2016; Padachi and Bhiwajee, 2016), but a non-linear relationship could be present. As well as context individuals may vary in the extent to which loss aversion may affect their choices. The next sub-section covers one such theory that of Higgin's $(1997 ; 2009)$ regulatory focus.

\subsection{Regulatory Focus}

Extant research indicates the importance of the firm owners in making decisions relating to human resource development (Nolan and Garavan, 2016a); in particular, their values and personalities are deemed critical (De Winne and Sels, 2010). Three distinctions have been introduced by regulatory focus theory, how achievement of success is considered, the influence upon acts of omission and commission and emotional influences on risky decision making (Bryant and Dunford, 2008). There are two motivational systems seen to guide the behaviour of individuals, the prevention and promotion systems (Higgins, 2009). The prevention system is concerned with duties, responsibilities, and security, which means that it links to oughts. By this it is meant what the individual or important others believe ought to be or should be achieved rather than targeting an ideal outcome (Higgins, 1997). It is more applicable for situations where outcomes involve suffering a loss, or avoiding this loss, as there is greater sensitivity to negative rather than positive outcomes. This leads to strategies based on avoiding particular outcomes and so, reducing the chances of making incorrect choices (Higgins and Spiegel, 2004). Fewer actions are undertaken as it is deemed better to avoid an 
inappropriate choice than risk missing out upon a correct choice (Higgins, 1997). Emphasis is placed on quality and accuracy to reduce risks (Higgins and Spiegel, 2004).

The promotion system on the other hand relates to advancement, aspirations, and accomplishment. Higgins (2002), shows that promotion-focused people are more likely to value decisions made in the pursuit of gains. The focus links to ideals rather than 'oughts'; it is applicable to situations where the outcomes are obtaining, or not obtaining a gain. Strategies employed involve identifying correct choices and minimising the correct choices potentially missed. This leads to greater actions to reduce the risk of missing positive outcomes (Higgins, 1997). Decisions can be taken swiftly as volume of accomplishments outweighs any risks (Higgins and Spiegel, 2004). Although individuals are guided by both systems, one may dominate and lead to being more promotion or prevention focused. Experiments have shown that it is possible to place participants in a promotion or prevention focus through framing of activities so they are developed around ideals or oughts (Higgins et al., 1994). However, some individuals can have natural dispositions towards a promotion or prevention focus (Higgins et al., 1994).

Regulatory focus has been shown to be of relevance for SME management (Wallace et al., 2010; Johnson et al. 2017; Adomako et al., 2017). Hybrid-entrepreneurs (combining entrepreneurship and employment), if promotion focused, will contribute more time to the venture even if it presents greater risks; if prevention focused, this strategy must be deemed to lower risk (Burmeister-Lamp et al., 2012). Prevention focused questions by potential investors are found to elicit prevention focused responses from owners, which reduces the average funding obtained (Kanze et al., 2018). Brockner et al. (2004) indicate that entrepreneurial activities are not always hindered by a prevention focus; for example, when undertaking due diligence of ideas. However, for opportunity recognition a promotion focus may compensate where task specific self-efficacy is lower (Tumasjan and Braun, 2012). Similarly, Kammerlander et al. (2015) find a prevention focus is negatively 
associated with identifying new opportunities (exploratory activities), but benefiting from existing opportunities (exploitative activities) is not influenced.

SME management performance may be related to regulatory focus, but contingent upon the operating environment. In more dynamic environments characterised by uncertainty, promotion focused individuals retain flexibility to adapt to changes enabling exploration of emerging opportunities (Hmieleski and Baron, 2008; Trevelyan, 2011). Prevention focused individuals function as well in stable environments characterised by risk, allowing exploitation of existing opportunities (Hmieleski and Baron, 2008; Trevelyan, 2011). Where tasks become difficult, prevention focused individuals are more likely to quit, meaning promotion orientated business owners self-select or remain in more dynamic environments (Crowe and Higgins, 1997). Investments in managerial human capital may help regardless of the environment, but where new challenges are emerging in dynamic environments, promotion orientated business owners may be more likely to invest in such skills.

Given this analysis, the expectation is that those who are promotion focused will be willing to take more risks in terms of investing in managerial human capital in order to achieve the gains that are their goals (Tumasjan and Braun, 2012). Promotion focused owners will be more concerned with errors of omission in terms of skills and productivity gains rather than potential losses associated with opportunity costs (Crowe and Higgins, 1997; Higgins and Spiegel, 2004). This leads to the third hypothesis to be tested:

H3: More promotion focused business owners will be more likely to invest in managerial human capital.

An alternative perspective can be drawn from combining work on regulatory focus with that covered in the preceding section on prospect theory. Those with a more prevention focus can be considered as placing more emphasis on remaining at the status quo (avoiding losses). Where a loss has been suffered, they will focus on returning to the status quo and may be willing to adopt risk seeking 
behaviour to this end (Scholer et al., 2010). Normally the expectancy of success and value of effects are assumed to have a multiplicative relationship with motivation (Feather, 1982). In practice this is not always the case (Shah and Higgins, 1997). One explanation being that in a prevention focus, as value increases it becomes a necessity, and individuals will attempt to achieve this prevention goal regardless of the chances of success. A firm's survival could be at risk where a loss has been suffered meaning a prevention focused owner may throw all remaining resources at risky options, such as managerial training, to avoid this outcome. This means that an interaction may exist between whether a loss or gain has been experienced and the prevention focus of individuals:

H4: More prevention focused business owners/managers will be more likely to invest in managerial human capital where a loss has been experienced.

Our analysis indicates a potentially complex relationship between gains, losses, and regulatory focus of SME owners. The following section outlines the LSBS data and analysis approaches used to explore this in more detail.

\section{Data and Methods}

\subsection{Data}

The study utilises data drawn from the Longitudinal Small Business Survey (LSBS) from 2015 and 2016 (Department for Business Innovation and Skills, 2016) to examine whether the characteristics in 2015 are related to those in 2016. This reduces the chances of reverse causality being the explanation for any relationship found. Telephone interviews with business owners and managers of private sector SMEs (250 or fewer employees) were used to collect data from firms identified through the Inter Departmental Business Register (IDBR) and Dun and Bradstreet's database. The survey was stratified according to three dimensions, the four UK nations, firm size based on employment, and industry sector. Firms with zero employment are included as are firms that are not registered as companies. According to the Department for Business, Energy and Industrial Strategy 
(2017) firms with no employment account for 76 percent of all businesses in the UK and therefore, their decisions with regard to managerial training and the form this takes could have considerable bearing on the provision and support from private and public sector organisation required.

15,502 interviews were conducted in 2015 followed by 7279 in 2016, although a further 1969 top up interviews were conducted to maintain sample size in future years. From the dataset 5306 firms have all required data available for both 2015 and 2016.

One concern that may need to be taken into account is the timing of the 2016 wave of interviews (August 2016 to January 2017); this coincides with the period immediately after the UK referendum on membership of the European Union. The UK economy and business sentiments initially remained relatively robust (Gross, 2016), suggesting that the impact at that time, was not overly detrimental. However, it is possible that longer-run investments from foreign direct investment (Ebell and Warren, 2016) and new ventures will be delayed or diverted to other countries (Cumming and Zahra, 2016). Similarly, real option theories of investment suggest that greater political or economic uncertainty from Brexit will delay irreversible investments in inputs such as managerial human capital (Dixit and Pindyck, 1994; Binding and Dibiasi, 2017; Jens, 2017).

\subsection{Measures of Managerial Training}

Respondents were asked whether managers in the business have received any training in the last 12 months. Overall provision of training is captured by a dummy reflecting managers experiencing training from any single or combination of sources. As much training in SMEs is informal in nature (Section 2) two separate dummy variables are created reflecting whether managers have experienced informal on the job training (regardless of whether they have or haven not received formal training) and formal off the job training (likewise, ignoring informal training). All data is taken from the 2016 responses of the owners/managers, but will be regressed on the 2015 data used to create the independent variables. 


\subsection{Promotion and Prevention Focus}

As decision making is influenced by two separate systems, a measure for each is required (Higgins, 1997). Promotion focus is linked to achieving goals associated with ideals (Higgins, 1997), such as being a large, innovative, employer of skilled workers (Kerr et al., 2018). In order to establish the ideals we draw upon those measures associated with SME performance either as direct measures or those leading to improved performance in previous studies. Five areas of ambition for the future of the owner/manager's firm are utilised: sales growth (Dabic et al., 2018; Irwin et al., 2018); innovation intentions (Cowling, 2016; Dabic et al., 2018; Irwin et al., 2018); plans to improve staff skills (Dabic et al., 2018); investments in physical capital (Gerlach-Kristen et al., 2015) and employment growth (Irwin et al., 2018). Seven items are utilised:

- Intention to grow sales over the next three years (sales promotion)

- Plans to develop and launch new products/services (innovation promotion)

- Plans to introduce new working practices (innovation promotion)

- Plans to increase the skills of the workforce (skills promotion)

- Plans to increase the leadership capacity of managers (skills promotion)

- Plans to make capital investment (investment promotion)

- Expectations of employing more people (employment promotion)

For each aspect of promotion a value of 1 was given where the element was present and zero otherwise. Where two items covered the same aspect of promotion, such as for innovation, a value of 1 was given where at least one was present. The five aspects of promotion were then summed to produce an overall promotion focus variable taking values from 0 no promotion focus, to 5 promotion focus across all aspects. Alternatives were considered including exporting ambitions, but it was felt this would in part be captured by sales growth ambitions and also, is relatively rare for UK SMEs (Thompson and Zang, 2016). It should be noted that the ambitions outlined above relate more 
to extrinsic measures of success, whereas SME owners may value intrinsic measures such as worklife balance (Weber and Geneste, 2014).

For prevention focus it would have been desirable to generate a similar scale, but few relevant items were present in the 2015 data. Instead a dummy was used where there was some evidence of prevention focus. First where firms have not consistently exported the reasons for this are asked. Two items picking out a safety first and preservation of the status quo are used:

- The reason for not exporting in some years is that exporting is too risky

- The reason for not exporting in some years is that I prefer to concentrate on UK markets.

Only a small number of respondents (34) indicated that either of the above explained their inconsistent exporting activity. The alternative measure is based around seeking external finance for safety and security:

- Sought finance to protect intellectual property rights.

- Sought finance to consolidate existing debt.

For those not seeking finance, reasons that reflected a preference to not risk the status quo were drawn upon:

- Did not seek finance because I did not wish to add to risk

- Did not seek finance because it was not appropriate in the current economic conditions

The prevention measure is a dummy reflecting the presence of at least one of the above export, finance seeking and finance avoidance measures associated with safety and security. Only 345 respondents were classed as displaying prevention focus, which may reflect self-selection away from business ownership. Measures were purposively sought that reflected issues relating to safety and security rather than any relating to failings of the manager to try and avoid any bias in responses. However, there is still potential that some prevention focused individuals did not wish to appear as 
such, either wishing to conform to the image of the successful business owner, or looking for justifications for choices that preserved their own self-image.

\subsection{Gains and Losses}

Difficulties defining reference points due to their subjective and multi-dimensional natures (Fiegenbaum et al., 1996; Shinkle, 2012), makes using large secondary datasets imperfect but has the benefit of larger sample sizes. We consider whether turnover has increased, remained the same or decreased compared to the previous year, as captured in 2015 as past outcomes are deemed influential (Köszegi and Rabin, 2009). Regardless of the reality of such outcomes, if owners/managers feel they have suffered a decline in performance this is key psychological driver. Such a reference point is likely to be of importance to both the promotion focused trying for an ideal of creating a larger business, and the prevention focused where falling turnover is likely to put the survival of the business at risk.

\subsection{Analysis Approach}

A regression analysis approach is used to test whether relationships remain after controlling for other influences. The discrete nature of the investment in managerial human capital variables makes ordinary least squares regressions inappropriate. A binary logistic regression approach is employed that examines the probability of making a particular choice (the decision to invest in managerial human capital) based on the cumulative logistic probability function. The log of the odds of the outcome is regressed on the independent variables:

$$
\log \frac{\hat{P}_{j i}}{1-\hat{P}_{j i}}=\alpha_{j 0}+\beta_{j 1} \operatorname{Prom}_{i}+\beta_{j 2} \operatorname{Prev}_{i}+\beta_{j 3} \operatorname{Gain}_{i}+\beta_{j 4} \operatorname{Loss}_{i}+\gamma_{j 1} X_{i}+\varepsilon_{j i}
$$

Where the dependent variable is based on the estimated probability of investing in managerial human capital (MHCap).

$\hat{P}_{j i}=\operatorname{Prob}\left(\mathrm{MHCap}_{j}\right)$ 
A separate regression is run for each type of training (j) (on the job, off the job and all training). As outlined above, two variables are included to represent the promotion (Prom) and prevention (Prev) focus of owner/manager i. Gain and Loss are two dummy variables representing having experienced a turnover increase or decrease compared to the previous year, which are compared to the base category of turnover remaining unchanged. $X$ represents the other business owner and firm characteristics that are controlled for.

The possibility of an interaction between the prospect theory and regulatory focus variables is allowed for as in equation 5 below:

$$
\begin{aligned}
& \log \frac{\hat{P}_{j i}}{1-\hat{P}_{j i}}=\alpha_{j 0}+\beta_{j 1} \operatorname{Prom}_{i}+\beta_{j 2} \operatorname{Prev}_{i}+\beta_{j 3} \operatorname{Gain}_{i}+\beta_{j 4} \text { Loss }_{i}+ \\
& \beta_{j 5} \operatorname{Prom}_{i} \cdot \operatorname{Gain}_{i}+\beta_{j 6} \operatorname{Prom}_{i} \cdot \operatorname{Loss}_{i}+\beta_{j 7} \operatorname{Prev}_{i} \cdot \operatorname{Gain}_{i}+\beta_{j 8} \operatorname{Prev}_{i} \cdot \operatorname{LosS}_{i}+\gamma_{j 1} X_{i}+\varepsilon_{j i}
\end{aligned}
$$

For clarity of understanding we run specifications that have interactions between: the prospect theory variables and just promotion focus; prospect theory variables and prevention focus; and all interactions.

\subsection{Control Variables}

Both demand and supply influences on investments in managerial human capital may relate to firm leadership and characteristics. Where the owner-manager is dominant and the firm less structured, training is less likely to formalised (Reid et al., 2002; Wong et al., 1997). Reflecting diversification of control and a fuller structure the natural log of the number of directors and partners plus one is included. Larger SMEs tend to have a more formalised approach to investments in human capital (Wapshott and Mallett, 2015; Almeida and Aterido, 2015). Growth is also likely to require managers to develop new skills to deal with the increasing complexity (Jayawarna et al., 2006), although, relatively few managers on Danish high growth training programmes are employees in high growth firms (Bager et al., 2015). To accommodate this, the natural log of employees plus 1 is included. 
As noted above the sample used includes all SMEs including those with no employees due to their considerable presence within the SME population as a whole. Acknowledging the potential for the more formalised human resource management approaches in larger SMEs we repeat the estimations using subsamples containing: only firms with employees; firms with no employees; SMEs excluding micro firms (less than 10 employees); and micro firms. To preserve space we do not report these results in full, but acknowledge in the text where differences are present; the full results are available from the authors on request. Human capital investment choices may become more informed as firms become established with better networks allowing access to information on the choices available (Baldwin et al., 1995). To capture this, the natural log of years since establishment plus 1 is included in the regression.

Studies have suggested that both female led businesses and those classed as ethnic businesses have additional resource restrictions of various types compared to non-minority male led businesses. These resource restrictions fall into three main groups: money, markets and managerial skills (Carter et al., 2015). In terms of the first two these may limit the potential to seek costly training (Panagiotakopoulos, 2011; Barrett, 2015; Padachi and Bhiwajee, 2016). For example, female and minority business owners may have less access to finance to fund managerial training due to a number of factors including structural and sectoral factors (Bruder et al., 2011), and actual or perceived discrimination (Freel et al., 2012; Carter et al., 2015; Galli et al., 2018).

Traditionally many female led and ethnic minority businesses have been clustered in low value added sectors with lower barriers to entry, such as consumer services and health for female led businesses and retail and catering for ethnic minorities (Carter et al., 2015; Edwards et al., 2016). It is suggested there is a "leaky pipeline" which means progressively few women advance through stages of education and into employment in the science engines and technology fields (Martin et al., 2015). This leads to a greater presence in less research and technology intensive sectors where formalised training may be perceived to have less benefit (Manresa and Bikfalvi, 2018). In order to 
survive in highly competitive markets ethnic minority businesses owners have had to work long hours (Jones and Ram, 2011), which will increase the perceived high opportunity cost of training noted previously (Cardon and Valentin, 2018; Rahman et al., 2018).

However, limited managerial skills could mean there is a greater need for investments in managerial training (Schneider, 2017). On average studies have found female business owners to be less likely to possess formal business education and managerial experience (Poggesi et al., 2015). Further investments could be encouraged where female business owners have lower confidence in their abilities due to work experiences having less impact on the entrepreneurial self-efficacy (Kickul et al., 2008).

UK business owners from ethnic minority backgrounds have indicated that much formal training and support is not appropriate for their businesses, or those providers are not trusted (Ram et al., 2006; Ram et al., 2012). This may particularly the case where the training is provided by those not embedded within their community and sector, so language or cultural barriers may be present (Edwards et al., 2010; Nwankwo et al., 2010; Kremel, 2016). This can lead to a greater reliance on coethnic and extended family networks for support in general (Edwards et al., 2016). Interestingly it is both the most recent arrivals (Ram et al., 2012; Kremel, 2016), and older and experienced business owners who are first generation migrants (Thompson et al., 2010), who are likely to be affected. This may mean that off the job formalised training may not be adopted in businesses classed as ethnic minority led. Although, studies have indicated that sectoral concentration and cultural and language barriers are diminishing over time (Thompson et al., 2010; Bates, 2011; Carter et al., 2015), there may still be an effect.

To represent the above effects on investments in managerial human capital for female led and ethnic minority businesses, dummy variables are included to represent each. However, it should be noted that these will capture an overall effect of the above influences, which in some cases may operate in different directions. 
Industry controls are included that split the firms into six categories (primary; manufacturing; construction; retail, accommodation and transport; business services and others services). These help to capture some of the different needs of businesses operating in particular sectors that may alter demands for managerial training. As innovation requires new knowledge a positive association with training is found (Sung and Choi, 2014; Whittaker et al., 2014; Manresa and Bikfalvi, 2018). To overcome resource constraints open innovation through collaboration with others to access new knowledge may be of even greater importance for SMEs (Chesbrough, 2003; Marques and Ferreira, 2009). For SMEs, customers and suppliers form the main sources of collaboration for open innovation (Vahter et al., 2014). The regressions therefore, include two dummy variables, one capturing innovation conducted without collaboration with other firms, and one capturing that involving collaboration with other firms.

\section{Results}

Tables 1 to 4 present the proportions of owners/managers investing in managerial human capital when dividing the sample by prospect theory and regulatory focus theory variables. Table 1 presents the results for formal off the job training.

\section{PLEASE INSERT TABLE 1 ABOUT HERE}

Overall, a strong significant positive relationship between turnover growth in 2015 and investments in formal off the job training is found consistent with hypothesis $H 1$. The availability of resources and need for more skills may well have encouraged investments in skills (Castany, 2010; Antonioli and Della Torre, 2016). However, there is considerably less difference between those experiencing a loss and those that retained previous turnover levels. Although there is no statistical support for hypothesis $H 2$, it does appear a loss does not discourage all owners/managers from making an investment (Scholer et al., 2010). Tables 2 and 3 indicate that this result is consistent regardless of the type of training being considered. 


\section{PLEASE INSERT TABLES 2 AND 3 ABOUT HERE}

For all managerial training, regardless of whether it is on or off the job (Table 3) less than one in five of those owners/managers with no promotion focus make such investments (18.1\%). Where all five dimensions are present, nearly two in three of owners/managers make such investments in the following year (65\%). The positive pattern consistent with hypothesis $\mathrm{H3}$ is present for both formal off the job training (Table 1) and informal on the job training (Table 2).

A promotion focus is positively associated with the likelihood of an owner/manager investing in all types of managerial human capital, regardless of whether a gain or loss is experienced. However, for individual levels of promotion focus there is not necessarily an increase in the proportion of owners/managers investing in managerial human capital due to experiencing a gain. For example, when only one dimension of promotion focus is present the percentage of owners/managers investing in formal off the job managerial training is actually higher for those suffering a loss (22\%) than a gain (15.9\%) (Table 1). It appears that in most cases, the positive influence of experiencing a gain on managerial training is more obvious at the higher levels of promotion focus. Figure 2 below presents the results from Table 1.

\section{PLEASE INSERT FIGURE 2 ABOUT HERE}

When a moderate or greater promotion focus is present a higher percentage of those experiencing gains are found to invest in managerial human capital (e.g. compared to no growth and 3 dimensions of promotion $\chi^{2}=4.596$, d.f. [1], $p$-value $=0.032$ ), driven by differences in formal off the job training (gain $v$ reference point and 3 dimensions of promotion $\chi^{2}=6.492$, d.f. [1], p-value $=0.011$ ). This difference disappears for those with a small amount of promotion focus. Where two dimensions of promotion focus are present it is actually reversed. For those experiencing a loss there is weak evidence they are less likely to invest in managerial training than those experiencing neither a gain or loss $\left(\chi^{2}=3.301\right.$, d.f. [1], $p$-value $\left.=0.069\right)$. Table 4 considers the impact of prevention focus. For 
formal off the job training a slightly higher percentage make investments when prevention focused, but the pattern is reversed when considering informal on the job training, but these differences are not statistically significant.

\section{PLEASE INSERT TABLE 4 ABOUT HERE}

For formal off the job training investments are lowest when a loss has been experienced. However, for informal on the job training being prevention focused reverses the pattern (38.5\% invest when a loss has been experienced, but only $33.9 \%$ when there is no gain or loss). The difference is not significant so hypothesis $\mathrm{H} 4$ cannot be supported, but those suffering losses are no more likely to shy away from such investments $\left(\chi^{2}=0.447\right.$, d.f. [1], $p$-value $\left.=0.504\right)$.

Table 5 below in preparation for the multivariate analysis presents the correlation matrix. Variables such as turnover growth capturing gains and losses are ordinal therefore the Spearman rank correlations are reported.

\section{PLEASE INSERT TABLE 5 ABOUT HERE}

Those firms that engage in formal training are also more likely to be those conducting informal training on the job $(\rho=0.633)$. There is evidence for a positive relationship between promotion focus and all forms of job training, but no significant relationship is found for those with a degree of prevention focus. The turnover growth variable is also positively related to training.

In addition, larger, more established, female led, non-ethnic minority led, innovative businesses with more directors are positively associated with investments in training. This fits with the availability of resources (Sung and Choi, 2016) and need for more specialisation (Castany, 2010; Antonioli and Della Torre, 2016) driving uptake of training. Female led businesses being more likely to engage in managerial training is also found by previous studies potentially due to shortages in management skills (Kickul et al., 2008; Carter et al., 2015). The lack of trust expressed by ethnic minority business owners with regard to mainstream advice and support makes the negative relationship for ethnic 
minority led businesses unsurprising (Ram et al., 2006, 2012). The correlations between the independent variables suggest no problems of multicollinearity, confirmed by the variance inflation factors where the maximum of 1.635 for 'Other Services' is well below the conventional cut-off of 10.

Tables 6 to 8 below present the binary logistic regression results for formal off the job managerial training, informal on the job managerial training, and all managerial training respectively. In all cases, the joint significance is confirmed at the 1 percent level. The percentage of deviation accounted for varies from around 23 percent to over 25 percent for each measure of managerial training, with just under 70 percent of outcomes correctly predicted in each case. The Hosmer and Lemeshow test indicates that a good fit to the data can only be rejected for model 3 in Table 6.

\section{PLEASE INSERT TABLE 6 ABOUT HERE}

Promotion focus is positively associated with formal investments in managerial human capital even after controlling for other characteristics (hypothesis H3). An increase by one dimension on promotion focus variable directly increases the likelihood of investing in off the job managerial training by between one fifth and a quarter (odds ratios: Model $1=1.265$, Model $6=1.216$ ). No significant relationship is found with prevention focus. Gains are associated with greater formal investments in managerial human capital, but no equivalent negative effect is found from suffering a loss. This is supportive of the traditional perspective relating to availability of resources and specialisation needs for expansion (hypothesis H1). Estimations run with subsamples of firms of different employment size indicate that this relationship is only present for firms with employees, but results are quantitatively similar, and qualitatively the same, when comparing micro and nonmicro SMEs.

There is no support for a positive effect from losses where owners/managers become more risk seeking (hypothesis $\mathrm{H} 2$ ). However, the lack of a significantly negative coefficient on losses means 
that hypothesis $\mathrm{H} 2$ cannot be dismissed out of hand. The lack of significant interaction terms between promotion focus or prevention focus and where a gain or loss has been experienced means there is no support for prevention focused owners/managers taking risks to try to return to the

reference point (hypothesis H4). Larger more structured businesses both in terms of their employment, and to a lesser extent the number of directors, are associated with formal investment in managerial human capital. Those engaging in open innovation are found to be half as likely again to be investing in formal managerial training (Model 6 odds ratio $=1.551$ ). Both results provide indirect support of hypothesis $H 1$ where specialisation needs and resources boost investments in managerial human capital. Female led businesses are around a third more likely to make an investment in formal managerial human capital (Model 6 odds-ratio $=1.358$ ). Ethnic minority led firms, however, are less than half as likely as those firms that are not minority led to make such investments (Model 6 odds-ratio $=0.462$ ).

Table 7 below indicates that largely, the relationships found for investments in formal off the job training are equally applicable for informal on the job training. A promotion focus is positively and independently associated with on the job managerial training, whilst prevention focus again has no significant relationship. The influence of a promotion focus is slightly greater than for formal training (odds ratios: Model $1=1.276$, Model $6=1.245$ ).

\section{PLEASE INSERT TABLE 7 ABOUT HERE}

There are however, also some subtle differences. The positive influence of experiencing a gain for formal off the job training (Table 6) disappears for informal on the job managerial training when controlling for promotion focus (Table 7). This suggests that for informal on the job managerial training it is hypothesis $H 3$ the promotion focus of owners/managers rather than hypothesis $H 1$ experiencing a gain, which is most important. When estimations are run just including firms without employees or micro firms the significant terms for gains disappear. This may reflect resource constraints when demand is high impinging to a greater extent on these firms (Garavan et al., 2016). 
Interestingly for informal on the job investments in managerial human capital there is weak evidence to support hypothesis $H 4$, that prevention orientated owners/managers will invest when they have experienced a loss to try and return to the reference point. In Model 6 the interaction term between prevention focus and a loss is positive and significant, albeit at the 10 percent level. Such a result for on the job training is understandable as those suffering a loss, whilst wishing to pursue a risky investment, may be resource constrained in terms of the options available.

Although most other variables retain similar relationships to those found for formal investments in managerial human capital, the negative coefficient on ethnic minority led businesses is smaller (Model 6 odds ratio $=0.699$ ), and in some regressions insignificant (Models 3 and 4). Distrust of more formalised mainstream providers rather than a cultural avoidance of training in general might explain this. The final set of results presented in Table 8 covering those undertaking managerial training of one type or another are similar to those presented for formal off the job training (Table 6).

\section{PLEASE INSERT TABLE 8 ABOUT HERE}

Support again is provided for hypothesis $\mathrm{H} 1$ that those experiencing gains are more likely to make investments in managerial human capital. Promotion orientated owners/managers are also more likely to make such investments (hypothesis H3). However, losses do not encourage or dissuade owners/managers from such risky investments (hypothesis H2). Positive interactions are found for prevention focus and suffering a loss, but they are not significant, so the weak support for hypothesis $\mathrm{H} 4$ is restricted to informal on the job managerial training.

\section{Conclusions}

This study has examined some of the psychological factors potentially influencing decisions to invest in SME managerial human capital. Using theory based on more traditional resource availability, prospect theory and regulatory focus it was predicted that: gains in the form of turnover growth 
would provide the resources to boost investments (hypothesis H1); losses from falling turnover would lead to risky investments in managerial human capital (hypothesis H2); promotion orientated owners/managers would be more likely to invest (hypothesis H3); and prevention focused owners/managers experiencing a previous loss would be more likely to make such investments (hypothesis $H 4$ ).

Data from the LSBS provided evidence to support hypotheses $H 1$ and $H 3$. Support for the positive effect of a promotion focus (hypothesis H3) was found for all sub-groups of firms based on employment including those without employees, while the effect of additional resources (hypothesis H1) was less apparent for subsamples of micro firms and those without employees. Although suffering a loss did not reduce the likelihood of making such an investment as resource availability might suggest, no positive relationship was present. Hypothesis $\mathrm{H} 2$ might still hold, but is in part being offset, so that no clear evidence is present in the data. Weaker evidence was indicated for hypothesis $\mathrm{H} 4$, but only for more informal on the job managerial training.

Given that promotion focused business owners are likely to invest in a manager's human capital, policymakers looking to boost productivity, through encouraging and incentivising such investments (Antonioli et al., 2010; Manimala and Kumar, 2012; Enterprise Research Centre et al., 2015), particularly more formalised initiatives (Jayawarna et al., 2007; Clifton et al., 2015; Lai et al., 2017), would need to seek to produce a promotion focus. From the results, it appears counterproductive to focus on the dangers of falling behind the competition and the consequences for their families and the workforces; these are goals associated with security and responsibilities (prevention focus). Instead the opportunities for innovation and growth need to be highlighted. For many managers, these may hold less interest (Hurst and Pugsley, 2011), but in highlighting these the regulatory focus can be changed and a risky investment may be made. In regard to what form support should take, the danger is that as with past support such as the European Social Fund (ESF) Objective 4 Programme or the UK Government's Train to Gain a subset of particularly larger firms will access any 
financial support when much of the training would take place anyway (Devins and Johnson, 2004; Abramovsky et al., 2011). Support here should be more in the form of advising where training can be accessed rather than funding it. An approach that has become more popular in the UK in recent years Gregson (2018), however, the more active approach employed of the Mexican Ministry of Labor and Social Provision through regular visits to SMEs might be more successful although more costly (Lee, 2016). An alternative would be to combine this with an expansion of the Apprentice Levy to cover existing staff training where larger firms have to contribute into a fund, but can choose to direct this to SMEs within their supply chain (Department for Education, 2018). Given the selection and self-selection biases found by Bager et al. (2015) in terms of the managers that enrol on courses it will be of value to help advise upon which courses best suit managers and their companies to take advantage of any promotion focus formed. Such issues may be even more appropriate in emerging economies where the training market is less developed (Bai et al., 2017).

Business owners may be more receptive when gains have been achieved due to increased needs for specialised skills (Castany, 2010; Antonioli and Della Torre, 2016), financial resource availability (Sung and Choi, 2016), and also possibly because of greater optimism from promotion pride from meeting their ideals (Grant and Higgins, 2003). However, this would potentially exclude those struggling with losses. The study found weak evidence that experiencing a loss and being prevention orientated encourages informal on the job training, perhaps a last risky attempt to return to the reference point (Scholer et al., 2010). Where local economies have been affected by industry or area specific negative economic shocks subsidised or free training may be more widely embraced. This might include funding on the job training to cover any opportunity costs of lost production. Here the framing of the training can be about the benefits for survival.

As well as policymakers, it is important for research to incorporate issues of gains and losses and regulatory focus into analyses of risky decisions. This informs explanations of why apparently similar business owners may make different decisions, or individual business owners change choices over 
time. Accounting for psychological elements, will help to provide more clarity about other influences on their choices.

The use of secondary data does of course provide some limitations to the study. The timing of the data collection in the aftermath of the European Union membership referendum could affect the results. Making it beneficial to repeat the analysis with data from SMEs in other countries less exposed to such a specific shock, or in other periods for the UK. There is also no direct way to determine the appropriate reference point and studies have found firms may be affected by a number of reference points relating to different outcomes from their business simultaneously (Fiegenbaum et al., 1996; Shinkle, 2012). Similarly, the measurement of promotion and prevention focus could be improved. It was possible to produce a scale of promotion focus, but the 2015 LSBS did not allow an equivalent to be developed for prevention. In order to capture promotion and prevention focus an understanding of ideals and oughts sought would be valuable and help to incorporate intrinsic measures of success to a greater degree, particularly if such ideals differ between particular groups of SME owners, such as female business owners (Weber and Geneste, 2014). Where data is collected specifically for the purpose, this problem can be overcome, although replicating the same size of sample for such a study would be costly. Working with policymakers to embed these items within existing surveys would be the best way forward. Experimental approaches either in the field or laboratory would be an alternative, but this again would be costly. As noted above the findings here focus on investments in managerial human capital, but the results should be relevant for other investments, and further study should look to determine the consistency of results. Qualitative studies would provide further insight into the specific influences of gains and losses, promotion and prevention focus, and their interactions on decision making.

This article has found that psychological factors play an important role in the likelihood of owners/managers making investments in managerial human capital. As researchers and policymakers alike look to understand the limited productivity growth in the UK over the last 10 
years and to encourage such investments to boost it, it is clear that these findings have great relevance and importance. 
References

Abramovsky L, Battistin E, Fitzsimons E, Goodman A and Simpson H (2011) Providing employers with incentives to train low-skilled workers: evidence from the UK employer training pilots. Journal of Labor Economics 29(1): 153-193.

Adomako S, Opoku RA and Frimpoing K (2017) The moderating influence of competitive intensity on the relationship between CEOs' regulatory foci and SME internationalization. Journal of International Management 23(3): 268-278.

Almeida RK and Aterido R (2015) Investing in formal on-the-job training: are SMEs lagging much behind?. IZA Journal of Labor and Development 4: article number 8. doi:10.1186/s40175-015-0029-3 Antonioli D and Della Torre E (2016) Innovation adoption and training activities in SMEs. International Journal of Human Resource Management 27(3): 311-337.

Antonioli D, Mazzanti M and Pini P (2010) Productivity, innovation strategies and industrial relations in SMEs. Empirical evidence for a local production system in northern Italy. International Review of Applied Economics 24(4): 453-482.

Bager E, Jensen KW, Nielsen PS and Larsen TA (2015) Enrollment of SME managers to growthorientated training programs. International Journal of Entrepreneurial Behavior and Research 21(4): 578-599.

Bai Y, Yuan J, and Pan J (2017) Why SMEs in emerging economies are reluctant to provide employee training: evidence from China. International Small Business Journal 35(6): 751-766.

Baldwin JR, Gray T and Johnson J (1995) 'Technology use, training and plant-specific knowledge in manufacturing establishments', Ottawa: Statistics Canada Analytical Studies Branch research paper series, \#86. 
Barberis NC (2013) Thirty years of prospect theory in economics: a review and assessment. Journal of Economic Perspectives 27(1): 173-196.

Barrett R (2015) Small firm training: just meeting the day-to-day needs of the business. Employee Relations 37(5): 547-567.

Bates T (2011) Minority entrepreneurship. Foundation and Trends ${ }^{\circledR}$ in Entrepreneurship 7(3/4): 151311.

Baucells M, Weber M and Welfens F (2011) Reference-point formation and updating. Management Science 57(3): 506-519.

Beynon MJ, Jones P, Pickernell D and Packham G (2015) Investigating the impact of training influence on employee retention in small and medium enterprises: a regression-type classification and ranking believe simplex analysis on sparse data. Expert Systems 32(1): 141-154.

Binding G and Dibiasi A (2017) Exchange rate uncertainty and firm investment plans evidence from Swiss survey data. Journal of Macroeconomics 51: 1-27.

Blettner DP, He Z-L, Hu S and Bettis RA (2015) Adaptive aspirations and performance heterogeneity: attention allocation among multiple reference points. Strategic Management Journal 36(7): 9871005.

Brockner J, Higgins ET and Low MB (2004) Regulatory focus theory and the entrepreneurial process. Journal of Business Venturing 19(2): 203-220.

Bruder J, Neuberger D and Räthke-Döppner S (2011) Financial constraints of ethnic entrepreneurship: evidence from Germany. International Journal of Entrepreneurial Behaviour and Research 17(3): 296-313.

Bryant P and Dunford R (2008) The influence of regulatory focus on risky decision-making. Applied Psychology 57(2): 335-359. 
Burmeister-Lamp K, Lévesque M and Schade C (2012) Are entrepreneurs influenced by risk attitude, regulatory focus or both? An experiment on entrepreneurs' time allocation. Journal of Business Venturing 27(4): 456-476.

Cardon MS and Valentin SD (2018) Training and development in small and medium enterprises. In: Brown KG (ed) The Cambridge Handbook of Workplace Training and Employee Development, New York, NY: Cambridge University Press, pp. 363-382.

Carter S, Mwaura S, Ram M, Trehan K and Jones T (2015) Barriers to ethnic minority and women's enterprise: existing evidence, policy tensions and unsettled questions. International Small Business Journal 33(1): 49-69.

Castany L (2010) The role of size in firms' training: evidence from Spain. International Journal of Manpower 31(5): 563-584.

Chesbrough H (2003) Open Innovation: The New Imperative for Creating and Profiting from Technology. Boston, MA: Harvard Business School Press.

Christensen CM and Raynor ME (2003) The Innovator's Solution: Creating and Sustaining Successful Growth. Boston, MA: Harvard Business School Press.

Clifton N, Huggins R, Morgan B and Thompson P (2015) An appropriate tool for entrepreneurial learning in SMEs? The case of the 20Twenty Leadership Programme. Local Economy 30(5): 534-556.

Coetzer A, Redmond J and Sharafizad J (2012) Decision making regarding access to training and development in medium-sized enterprises: an exploratory study using the critical incident technique. European Journal of Training and Development 36(4): 426-447.

Cowling M (2016) You can lead a firm to R\&D but can you make it innovate? UK evidence from SMEs. Small Business Economics 46(4): 565-577. 
Crowe E and Higgins ET (1997) Regulatory focus and strategic inclinations: promotion and prevention in decision-making. Organizational Behavior and Human Processes 69(2): 117-132.

Cumming DJ and Zahra SA (2016) International business and entrepreneurship implications of Brexit. British Journal of Management 27(4): 687-692.

Cyert R and March J (1963) Behavioral theory of the firm. Upper Saddle River: Prentice Hall.

Dabic M, Lažnjak J, Smallbone D and Švarc J (2018) Intellectual capital, organisational climate, innovation culture, and SME performance: evidence from Croatia. Journal of Small Business and Enterprise Development. doi: 10.1108/JSBED-04-2018-0117

Department for Business, Energy and Industrial Strategy (2017) Business Population Estimates for the UK and regions 2017. London: National Statistics.

Department for Business Innovation and Skills (2016) 'Longitudinal Small Business Survey Year 1 (2015): Technical Appendix', BIS Research Paper Number, \#291.

Department for Education (2018) Guidance: Apprenticeship funding: how it works. Available at: https://www.gov.uk/government/publications/apprenticeship-levy-how-it-willwork/apprenticeship-levy-how-it-will-work (accessed 7 December 2018).

Devins D and Johnson S (2004) Training and development activities in SMEs: some findings from an evaluation of the ESF Objective 4 programme in Britain. International Small Business Journal 21(2): 213-228.

De Winne S and Sels L (2010) Interrelationships between human capital, HRM and innovation in Belgian start-ups aiming at an innovation strategy. International Journal of Human Resource Management 21(11): 1860-1880.

Dixit AK abd Pindyck RS (1994) Investment Under Uncertainty. Princeton, NJ: Princeton University Press. 
Ebell M and Warren J (2016) The long-term economic impact of leaving the EU. National Institute Economic Review 236: 121-137.

Edwards P, Ram M, Jones T and Doldor S (2016) New migrant businesses and their workers: developing, but not transforming, the ethnic economy. Ethnic and Racial Studies 39(9): 1587-1617. Edwards P, Sengupta S and Tsai C-J (2010) The context-dependent nature of small firms' relations with support agencies: a three-sector study in the UK. International Small Business Journal 28(6): 543-565.

Enterprise Research Centre, Goldman Sachs and British Business Bank (2015) Unlocking UK Productivity - Internationalisation and Innovation in SMEs. Warwick: ERC.

Feather NT (1982) Actions in relation to expected consequences: an overview of a research program. In: Feather NT (ed) Expectations and Actions: Expectancy-Value Models in Psychology. Hillsdale, NJ: Erlbaum, pp. 53-95.

Fiegenbaum A, Hart S and Schendel D (1996) Strategic reference point theory. Strategic Management Journal 17(3): 219-235.

Forth J, Bewley H and Bryson A (2006). Small and Medium Sized Enterprises: Finding from the 2004 Workplace Employment Relations Survey. London: DTI.

Freel M, Carter S, Tagg S and Mason C (2012) The latent demand for bank debt: characterizing 'discouraged borrowers'. Small Business Economics 38(4): 399-418.

Galli E, Mascia DV and Rossi SPS (2018) Does corruption influence the self-restraint attitude of women-led SMEs towards bank lending?. CESifo Economic Studies, 64(3): 426-455.

Garavan T, Watson S, Carbery R and O'Brien F (2016) The antecedents of leadership development practices in SMEs: the influence of HRM strategy and practice. International Small Business Journal 34(6): 870-890. 
Gehring WH and Willoughby AR (2002) The medial frontal cortex and the rapid processing of monetary gains and losses. Science 295(5563): 2279-2282.

Georgiadis A and Pitelis CN (2016) The impact of employees' and managers' training on the performance of small- and medium-sized enterprises: evidence from a randomized natural experiment in the UK service sector. British Journal of Industrial Relations 54(2): 409-421.

Gerhlach-Kristen P, O'Connell B and O'Toole (2015) Do credit constraints affect SME investment and employment?. Economic and Social Review 46(1): 51-86.

Grant $\mathrm{H}$ and Higgins ET (2003) Optimism, promotion pride, and prevention pride as predictors of quality of life. Personality and Social Psychology Bulletin 29(12): 1521-1532.

Gregson G, Mazdeh H, Raby S and Sauders C (2018) ‘Business support and SME performance: exploratory analysis of the Longitudinal Small Business Survey 2015 and 2016', ERC Research Paper, $\# 70$.

Gross D (2016) The economics of Brexit: it's not about the internal market - CEPS Commentary. Brussels: CEPS.

Heimonen T (2012) What are the factors that affect innovation in growing SMEs? European Journal of Innovation Management 15(1): 122-144.

Higgins D, Mirza M and Drozynska A (2013) Power, politics and learning: a social enactment of the SME owner/manager. Journal of Small Business and Enterprise Development 20(3): 470-483.

Higgins ET (1997) Beyond pleasure and pain. American Psychologist 52(12): 1280-1300.

Higgins ET (2002) How self-regulation creates distinct values: the case of promotion and prevention decision making. Journal of Consumer Psychology 12(3): 177-191. 
Higgins ET (2009) Regulatory fit in the goal-pursuit process. In: Moskowitz GB and Grant H (eds) The Psychology of Goals. New York, NY: Guilford Press, pp. 505-533.

Higgins ET, Roney C, Crowe E and Hymes C (1994) Ideal versus ought predilections for approach and avoidance: distinct self-regulatory systems. Journal of Personality and Social Psychology 66(2): 276286.

Higgins ET and Spiegel S (2004) Promotion and prevention strategies for self-regulation: a motivated cognition perspective. In: Baumeister RF and Vohs FD (eds) Handbook of self-regulation: Research Theory, and Applications. New York, NY: Guilford Press, pp. 171-187.

Hmieleski KM and Baron RA (2008) When does entrepreneurial self-efficacy enhance versus reduce firm performance?. Strategic Entrepreneurship Journal 2(1): 57-72.

Hoffmann AOI, Henry SF and Kalogeras N (2013) Aspirations as reference points: an experimental investigation of risk behaviour over time. Theory and Decision 75(2): 193-210.

Hoque K and Bacon N (2008) Investors in People and training the British SME sector. Human Relations 61(4): 451-482.

Hurst E and Pugsley BW (2011) What do small businesses do?. Brookings Papers on Economic Activity 43(2): 73-142.

Irwin KC, Landay KM, Aaron JR, McDowell WC, Marino LD and Geho PR (2018) Entrepreneurial orientation (EO) and human resources outsourcing (HRO): a "HERO" combination for SME performance. Journal of Business Research 90: 134-140.

Jayawarna D, Macpherson A and Wilson A (2006) Managers' perceptions of management development needs in manufacturing SMEs. Education + Training 48(8/9): 666-681. 
Jayawarna D, Macpherson A and Wilson A (2007) Training commitment and performance in manufacturing SMEs: incidence and approaches. Journal of Small Business and Enterprise Development 14(2): 321-338.

Jens CE (2017) Political uncertainty and investment: causal evidence from U.S. gubernatorial elections. Journal of Financial Economics 124: 563-579.

Johnson M, Monsen EW and MacKenzie NG (2017) Follow the leader or the pack? Regulatory focus and academic entrepreneurial intentions. Journal of Product Innovation Management 34(2): 181200.

Jones P, Beynon MJ, Pickernell D and Packham G (2013) Evaluating the impact of different training methods on SME business performance. Environment and Planning C 31(1): 56-81.

Jones T and Ram M (2011) Ethnic entrepreneurs and urban regeneration. In: Southern A (ed.) Enterprise, Deprivation and Social Exclusion: The Role of Small Business in Addressing Social and Economic Inequalities. London: Routledge, pp. 58-73.

Kahneman D and Tversky A (1979) Prospect theory: an analysis of decision under risk. Econometrica 47(2): 263-291.

Kammerlander N, Burger D, Fust A and Fueglistaller U (2015). Exploration and exploitation in established small and medium-sized enterprises: the effect of CEO's regulatory focus. Journal of Business Venturing 30(4): 582-602.

Kanze D, Huang L, Conley MA and Higgins ET (2018) We ask men to win and women not to lose: closing the gender gap in startup funding. Academy of Management Journal 61(2): 586-614.

Kerr SP, Kerr WR and Xu T (2018) Personality traits of entrepreneurs: a review of recent literature. Foundations and Trends ${ }^{\circledR}$ in Entrepreneurship 14(3): 279-356. 
Kickul J, Wilson F, Marlino D and Barbosa SD (2008) Are misalignments of perceptions and selfefficacy causing gender gaps in entrepreneurial intentions among our nation's teens?. Journal of Small Business and Enterprise Development 15(2): 321-335.

Kőszegi B and Rabin M (2006) A model of reference-dependent preferences. Quarterly Journal of Economics 121(4): 1133-1165.

Kőszegi B and Rabin M (2007) Reference-dependent risk attitudes. American Economic Review 97(4): 1047-1073.

Kőszegi B and Rabin M (2009) Reference-dependent consumption plans. American Economic Review 99(3): 909-936.

Kotey B and Folker C (2007) Employee training in SMEs: effect of size and firm type-family and nonfamily. Journal of Small Business Management 45(2): 214-238.

Kremel A (2016) Fulfilling the need of business advisory services among Swedish immigrant entrepreneurs: an ethnic comparison. Journal of Entrepreneurship and Public Policy 5(3): 343-364. Lai Y, Saridakis G and Johnstone S (2017) Human resource practices, employee attitudes and small firm performance. International Small Business Journal 35(4): 470-494.

Lee KW (2016) 'Skills training by small and medium-sized enterprises: innovative cases and the consortium approach in the Republic of Korea', ABI Working Paper, \#579.

Macpherson A and Jayawarna D (2007) Training approaches in manufacturing SMEs: measuring the influence of ownership, structure and markets. Education + Training 49(8/9): 698-719.

Manimala MJ and Kumar S (2012) Training needs of small and medium enterprise: findings from an empirical investigation. IIM Kozhikode Society and Management Review 1(2): 97-110. 
Manresa A and Bikfalvi A (2018) The use and determinants of training and development for creativity and innovation. International Journal of Innovation Management. Epub ahead of print 22 March 2018. DOI: 10.1142/S1363919618500627.

Marlow S, Taylor S and Thompson A (2010) Informality and formality in medium sized companies: contestation and synchronization. British Journal of Management 21(4): 944-966.

Marques CS and Ferreira J (2009) 'SME innovative capacity, competitive advantage and performance in a 'traditional' industrial region of Portugal', Journal of Technology and Innovation, 4 (4), 53-68. Martin LM, Warren-Smith I, Schofield C and Millman C (2013) Exploring SME advice and training needs for entrepreneurial rural firms. International Journal of Entrepreneurship and Innovation 14(2): 95-102.

Martin L, Wright L, Beaven Z and Matlay H (2015) An unusual job for a woman? Female entrepreneurs in scientific, engineering and technology sectors. International Journal of Entrepreneurial Behavior and Research 21(4): 539-556.

Mehra A, Langer N, Bapna R and Gopal R (2014) Estimating returns to training in the knowledge economy: a firm-level analysis of small and medium enterprises. MIS Quarterly 38(3): 757-771. Millán JM, Congregado E, Román C, van Praag M and van Stel A (2014) The value of an educated population for an individual's entrepreneurship success. Journal of Business Venturing 29(5): 612632.

Nolan CT and Garavan TN (2016a) Human resource development in SMEs: a systematic review of the literature. International Journal of Management Reviews 18(1): 85-107.

Nolan CT and Garavan TN (2016b) Problematizing HRD in SMEs: a "critical" exploration of context, informality, and empirical realities. Human Resource Development Quarterly 27(3): 407-442. 
Nwankwo S, Akunuir J, Madichie NO (2010) Supporting black businesses: narrative of support providers in London. International Journal of Entrepreneurial Behavior and Research 16(6): 561-580.

Onkelinx J, Manolova TS and Edelman LF (2016) The human factor: investments in employee human capital, productivity, and SME internationalization. Journal of International Management 22(4): 351364.

Padachi K and Bhiwajee SL (2016) Barriers to employee training in small and medium sized enterprises: insights and evidences from Mauritius. European Journal of Training and Development 40(4): 232-247.

Panagiotakopoulos A (2011) Barriers to employee training and learning in small and medium-sized enterprises (SMEs). Development and Learning in Organizations 25(3): 15-18.

Patton D and Marlow S (2002) The determinants of management training within smaller firms in the UK. What role does strategy play?. Journal of Small Business and Enterprise Development 9(3): 260270.

Perry J, Badger B, Lean J and Leybourne S (2010). Taking over the reins: the needs of individuals who purchase small established enterprises. International Journal of Entrepreneurship and Innovation 11(1): 57-67.

Peters R and Naicker V (2013). Small medium micro enterprises business goals and government support: A South African case study. South African Journal Business Management 44(4): 13-24. Poggesi S, Mari M and de Vita L (2015) What's new in female entrepreneurship research? Answers from the literature. International Entrepreneurship and Management Journal 23(3): 735-764.

Rabie C, Can MC and Wiid JA (2016) Training and development in SMEs: South Africa's key to survival and success?. Journal of Applied Business Research 32(4): 1009-1023. 
Rahman MdZ, Ullah F and Thompson P (2018) Challenges and issues facing ethnic minority small business owners: the Scottish experience. International Journal of Entrepreneurship and Innovation 19(3): 177-193.

Ram M, Jones T and Patton D (2006) Ethnic managerialism and its discontents: policy implementation and 'ethnic minority businesses. Policy Studies 27(4): 295-309.

Ram M, Trehan K, Rouse J, Woldesenbet K and Jones T (2012) Ethnic minority business support in the West Midlands: challenges and developments. Environment and Planning C 30(3): 504-519.

Reid RS, Morrow T, Kelly B and McCartan P (2002) People management in SMEs an analysis of human resource strategies in family and non-family businesses. Journal of Small Business and Enterprise Development 9(3): 245-259.

Schneider K (2017) Promoting the entrepreneurial success of women entrepreneurs through education and training. Science Journal of Education 5(2): 50-59.

Scholer AA, Zou X, Fujita K, Stroessner SJ and Higgins ET (2010) When risk seeking becomes a motivational necessity. Journal of Personality and Social Psychology 99(2): 215-231.

Shah J and Higgins ET (1997) Expectancy $\times$ value effects: regulatory focus as determinant of magnitude and direction. Journal of Personality and Social Psychology 73(3): 447-458.

Sheehan M (2013) Human resource management and performance: evidence from small and medium-sized firms. International Small Business Journal 32(5): 545-570.

Shinkle GA (2012) Organizational aspirations, reference points, and goals: building on the past and aiming for the future. Journal of Management 38(1): 415-455.

Sung SY and Choi JN (2014) Do organizations spend wisely on employees? Effects of training and development investments on learning and innovation in organizations. Journal of Organizational Behavior 35(3): 393-412. 
Sung SY and Choi JN (2016) To invest or not to invest: strategic decision making toward investing in training and development in Korean manufacturing firms. International Journal of Human Resource Management. Epub ahead of print 5 October 2016. DOI: 10.1080/09585192.2016.1239215.

Thompson P, Jones-Evans D and Kwong CCY (2010) Education and entrepreneurial activity: a comparison of White and South Asian men. International Small Business Journal 28(2): 147-162.

Thompson P and Zang W (2016) Foreign business ownership and domestic entrepreneurial exports. Journal of Small Business and Enterprise Development 23(3): 873-895.

Trevelyan R (2011) Self-regulation and effort in entrepreneurial tasks. International Journal of Entrepreneurial Behaviour and Research 17(1): 39-63.

Tumasjan A and Braun R (2012) In the eye of the beholder: how regulatory focus and self-efficacy interact in influencing opportunity recognition. Journal of Business Venturing 27(6): 622-636.

Tversky A and Kahneman D (1991) Loss aversion in riskless choice: a reference-dependent model. Quarterly Journal of Economics 106(4): 1039-1061.

Tversky A and Kahneman D (1992) Advances in prospect theory: cumulative representation of uncertainty. Journal of Risk and Uncertainty 5(4): 297-323.

Vahter P, Love JH and Roper S (2014) Openness and innovation performance: are small firms different?. Industry and Innovation 21(7/8): 553-573.

Van den Berg GJ, Dauth C, Homrighausen P and Stephan G (2018) Informing employees in small and medium sized firms about training: results of a randomized field experiment. IZA Discussion Paper $\# 11963$.

Walker E, Redmond J, Webster B and Le Clus M (2007) Small business owners: too busy to train?. Journal of Small Business and Enterprise Development 14(2): 294-306. 
Wallace JC, Little LM, Hill AD and Ridge JW (2010) CEO Regulatory foci, environmental dynamism, and small firm performance. Journal of Small Business Management 48(4): 580-604.

Wapshott R and Mallett O (2015) Managing Human Resources in Small and Medium-Sized Enterprises: Entrepreneurship and the Employment Relationship. Abingdon: Routledge.

Weber PC and Geneste L (2014) Exploring gender-related percxeptions of SME success. International Journal of Gender and Entrepreneurship 6(1): 15-27.

Westhead P and Storey D (1997) Management training in small firms - a case of market failure?. Human Resource Management Journal 7(2): 61-71.

Whittaker DH, Fath BP and Fiedler A (2014) Assembling capabilities for innovation: evidence from New Zealand SMEs. International Small Business Journal 34(1): 123-143.

Wilkinson N and Klaes M (2018) An Introduction to Behavioral Economics. London: Plagrave.

Wong C, Neil J, Marshal N, Alderman N and Thwaites A (1997) Management training in small and medium sized enterprises: methodological and conceptual issues. International Journal of Human Resource Management 8 (1): 44-65. 
Table 1 - Proportion Engaging in Off the Job Managerial Training in 2016 by Degree of Promotion Focus and Previous Change in Turnover

\begin{tabular}{lcccc}
\hline & \multicolumn{3}{c}{ Turnover Growth } \\
Degree of Promotion Focus & Negative (Loss) & None & Positive (Gain) & All \\
\hline 0 No Dimensions & $7.8 \%$ & $11.8 \%$ & $20.3 \%$ & $12.7 \%$ \\
1 & $22.0 \%$ & $20.8 \%$ & $15.9 \%$ & $19.8 \%$ \\
2 & $29.4 \%$ & $39.7 \%$ & $35.0 \%$ & $36.3 \%$ \\
3 & $41.0 \%$ & $40.6 \%$ & $48.6 \%$ & $43.6 \%$ \\
4 & $44.9 \%$ & $44.6 \%$ & $53.2 \%$ & $48.9 \%$ \\
5 All Five Dimensions & $45.9 \%$ & $51.2 \%$ & $59.9 \%$ & $56.4 \%$ \\
& & & & \\
Chi-square & 45.3 & 105.8 & 124.2 & 308.1 \\
d.f. & {$[5]$} & {$[5]$} & {$[5]$} & {$[5]$} \\
p-value & $(0.000)$ & $(0.000)$ & $(0.000)$ & $(0.000)$ \\
& & & & \\
Overall & $36.2 \%$ & $38.5 \%$ & $49.4 \%$ & $43.0 \%$ \\
$N$ & 803 & 2173 & 2330 & 5306 \\
& & & & \\
Chi-square [d.f] (p-value) & 72.6 & {$[2]$} & $(0.000)$ & \\
\hline
\end{tabular}

Table 2 - Proportion Engaging in On the Job Managerial Training in 2016 by Degree of Promotion Focus and Previous Change in Turnover

\begin{tabular}{lcccc}
\hline & \multicolumn{3}{c}{ Turnover Growth } \\
Degree of Promotion Focus & Negative (Loss) & None & Positive (Gain) & All \\
\hline 0 No Dimensions & $7.8 \%$ & $14.4 \%$ & $16.9 \%$ & $13.4 \%$ \\
1 & $24.4 \%$ & $21.2 \%$ & $17.7 \%$ & $20.9 \%$ \\
2 & $27.8 \%$ & $36.0 \%$ & $31.1 \%$ & $32.9 \%$ \\
3 & $40.1 \%$ & $39.8 \%$ & $43.2 \%$ & $41.1 \%$ \\
4 & $39.3 \%$ & $47.0 \%$ & $50.5 \%$ & $47.6 \%$ \\
5 All Five Dimensions & $45.9 \%$ & $51.2 \%$ & $58.0 \%$ & $55.2 \%$ \\
& & & & \\
Chi-square & 36.7 & 104.4 & 123.1 & 288.5 \\
d.f. & {$[5]$} & {$[5]$} & {$[5]$} & {$[5]$} \\
p-value & $(0.000)$ & $(0.000)$ & $(0.000)$ & $(0.000)$ \\
& & & & \\
Overall & $34.4 \%$ & $38.5 \%$ & $46.5 \%$ & $41.4 \%$ \\
$N$ & 803 & 2173 & 2330 & 5306 \\
& & & & \\
Chi-square [d.f] (p-value) & 49.0 & {$[2]$} & $(0.000)$ & \\
\hline
\end{tabular}


Table 3 - Proportion Engaging in Any Managerial Training in 2016 by Degree of Promotion Focus and Previous Change in Turnover

\begin{tabular}{lcccc}
\hline & \multicolumn{3}{c}{ Turnover Growth } & \\
Degree of Promotion Focus & Negative (Loss) & None & Positive (Gain) & All \\
\hline 0 No Dimensions & $10.9 \%$ & $19.0 \%$ & $23.7 \%$ & $18.1 \%$ \\
1 & $29.3 \%$ & $28.6 \%$ & $23.9 \%$ & $27.5 \%$ \\
2 & $37.3 \%$ & $46.6 \%$ & $42.8 \%$ & $43.7 \%$ \\
3 & $49.1 \%$ & $48.7 \%$ & $55.4 \%$ & $51.2 \%$ \\
4 & $54.7 \%$ & $55.2 \%$ & $61.3 \%$ & $58.2 \%$ \\
5 All Five Dimensions & $57.6 \%$ & $60.7 \%$ & $67.7 \%$ & $65.0 \%$ \\
& & & & \\
Chi-square & 57.1 & 116.8 & 134.3 & 341.6 \\
d.f. & {$[5]$} & {$[5]$} & {$[5]$} & {$[5]$} \\
p-value & $(0.000)$ & $(0.000)$ & $(0.000)$ & $(0.000)$ \\
& & & & \\
Overall & $44.7 \%$ & $47.1 \%$ & $57.1 \%$ & $51.1 \%$ \\
$N$ & 803 & 2173 & 2330 & 5306 \\
& & & & \\
Chi-square [d.f] (p-value) & 60.2 & {$[2]$} & $(0.000)$ & \\
\hline
\end{tabular}


Table 4 - Proportion Engaging in Managerial Training in 2016 by Degree of Prevention Focus and Previous Change in Turnover

\begin{tabular}{|c|c|c|c|c|}
\hline \multirow{2}{*}{$\begin{array}{l}\text { Type of Training } \\
\text { Panel A - Off the Job }\end{array}$} & \multicolumn{3}{|c|}{ Turnover Growth } & \multirow[b]{2}{*}{ All } \\
\hline & Negative & None & Positive & \\
\hline Not Prevention Focused & $36.4 \%$ & $38.3 \%$ & $49.2 \%$ & $42.9 \%$ \\
\hline Prevention Focused & $34.6 \%$ & $40.9 \%$ & $52.9 \%$ & $44.3 \%$ \\
\hline Overall & $36.2 \%$ & $38.5 \%$ & $49.4 \%$ & $43.0 \%$ \\
\hline Chi-square & 0.1 & 0.3 & 0.7 & 0.3 \\
\hline d.f. & {$[1]$} & {$[1]$} & {$[1]$} & {$[1]$} \\
\hline$p$-value & $(0.754)$ & $(0.555)$ & $(0.404)$ & $(0.588)$ \\
\hline Type of Training & \multicolumn{3}{|c|}{ Turnover Growth } & \\
\hline Panel B - On the Job & Negative & None & Positive & All \\
\hline Not Prevention Focused & $33.9 \%$ & $38.8 \%$ & $46.6 \%$ & $41.5 \%$ \\
\hline Prevention Focused & $38.5 \%$ & $33.9 \%$ & $45.0 \%$ & $39.4 \%$ \\
\hline Overall & $34.4 \%$ & $38.5 \%$ & $46.5 \%$ & $41.4 \%$ \\
\hline Chi-square & 0.6 & 1.2 & 0.1 & 0.6 \\
\hline d.f. & [1] & {$[1]$} & {$[1]$} & {$[1]$} \\
\hline$p$-value & $(0.423)$ & $(0.266)$ & $(0.709)$ & $(0.439)$ \\
\hline \multicolumn{2}{|l|}{ Type of Training } & \multicolumn{2}{|c|}{ Turnover Growth } & \\
\hline Panel C - All & Negative & None & Positive & All \\
\hline Not Prevention Focused & $44.4 \%$ & $47.1 \%$ & $56.9 \%$ & $51.1 \%$ \\
\hline Prevention Focused & $47.4 \%$ & $47.2 \%$ & $59.3 \%$ & $52.2 \%$ \\
\hline Overall & $44.7 \%$ & $47.1 \%$ & $57.1 \%$ & $51.1 \%$ \\
\hline Chi-square & 0.3 & 0.0 & 0.3 & 0.2 \\
\hline d.f. & {$[1]$} & {$[1]$} & {$[1]$} & [1] \\
\hline$p$-value & $(0.610)$ & $(0.978)$ & $(0.587)$ & (0.689) \\
\hline$N$ & 803 & 2173 & 2330 & 5306 \\
\hline
\end{tabular}


Table 5 - Correlation Matrix

\begin{tabular}{|c|c|c|c|c|c|c|c|c|c|c|c|}
\hline & $\begin{array}{l}\text { 1. Off the Job } \\
\text { Training }\end{array}$ & 2 & 3 & 4 & 5 & 6 & 7 & 8 & 9 & 10 & 11 \\
\hline 2. On the Job Training & $\begin{array}{c}0.633 \\
(0.000)\end{array}$ & & & & & & & & & & \\
\hline 3. Any Training & $\begin{array}{c}0.848 \\
(0.000)\end{array}$ & $\begin{array}{c}0.822 \\
(0.000)\end{array}$ & & & & & & & & & \\
\hline 4. Promotion Focus & $\begin{array}{c}0.222 \\
(0.000)\end{array}$ & $\begin{array}{c}0.222 \\
(0.000)\end{array}$ & $\begin{array}{c}0.235 \\
(0.000)\end{array}$ & & & & & & & & \\
\hline 5. Prevention Focus & $\begin{array}{c}0.007 \\
(0.588)\end{array}$ & $\begin{array}{c}-0.011 \\
(0.439)\end{array}$ & $\begin{array}{c}0.006 \\
(0.689)\end{array}$ & $\begin{array}{c}0.052 \\
(0.000)\end{array}$ & & & & & & & \\
\hline 6. Turnover Growth & $\begin{array}{c}0.114 \\
(0.000)\end{array}$ & $\begin{array}{c}0.096 \\
(0.000)\end{array}$ & $\begin{array}{c}0.104 \\
(0.000)\end{array}$ & $\begin{array}{c}0.244 \\
(0.000)\end{array}$ & $\begin{array}{l}-0.035 \\
(0.011)\end{array}$ & & & & & & \\
\hline 7. Employment & $\begin{array}{c}0.342 \\
(0.000)\end{array}$ & $\begin{array}{c}0.339 \\
(0.000)\end{array}$ & $\begin{array}{c}0.353 \\
(0.000)\end{array}$ & $\begin{array}{c}0.288 \\
(0.000)\end{array}$ & $\begin{array}{l}-0.060 \\
(0.000)\end{array}$ & $\begin{array}{c}0.130 \\
(0.000)\end{array}$ & & & & & \\
\hline 8. Female Business & $\begin{array}{c}0.076 \\
(0.000)\end{array}$ & $\begin{array}{c}0.089 \\
(0.000)\end{array}$ & $\begin{array}{c}0.076 \\
(0.000)\end{array}$ & $\begin{array}{l}-0.075 \\
(0.000)\end{array}$ & $\begin{array}{c}0.002 \\
(0.871)\end{array}$ & $\begin{array}{l}-0.034 \\
(0.012)\end{array}$ & $\begin{array}{c}-0.003 \\
(0.837)\end{array}$ & & & & \\
\hline 9 Ethnic Business & $\begin{array}{l}-0.056 \\
(0.000)\end{array}$ & $\begin{array}{c}-0.027 \\
(0.052)\end{array}$ & $\begin{array}{c}-0.046 \\
(0.001)\end{array}$ & $\begin{array}{c}0.056 \\
(0.000)\end{array}$ & $\begin{array}{c}0.041 \\
(0.003)\end{array}$ & $\begin{array}{l}-0.026 \\
(0.059)\end{array}$ & $\begin{array}{c}-0.031 \\
(0.026)\end{array}$ & $\begin{array}{l}-0.008 \\
(0.562)\end{array}$ & & & \\
\hline 10. Firm Age & $\begin{array}{c}0.039 \\
(0.004)\end{array}$ & $\begin{array}{c}0.035 \\
(0.011)\end{array}$ & $\begin{array}{c}0.035 \\
(0.012)\end{array}$ & $\begin{array}{l}-0.068 \\
(0.000)\end{array}$ & $\begin{array}{l}-0.048 \\
(0.001)\end{array}$ & $\begin{array}{c}-0.100 \\
(0.000)\end{array}$ & $\begin{array}{c}0.188 \\
(0.000)\end{array}$ & $\begin{array}{l}-0.006 \\
(0.653)\end{array}$ & $\begin{array}{c}-0.070 \\
(0.000)\end{array}$ & & \\
\hline 11. Number of Directors & $\begin{array}{c}0.076 \\
(0.000)\end{array}$ & $\begin{array}{c}0.060 \\
(0.000)\end{array}$ & $\begin{array}{c}0.070 \\
(0.000)\end{array}$ & $\begin{array}{c}0.135 \\
(0.000)\end{array}$ & $\begin{array}{l}-0.015 \\
(0.286)\end{array}$ & $\begin{array}{c}0.061 \\
(0.000)\end{array}$ & $\begin{array}{c}0.235 \\
(0.000)\end{array}$ & $\begin{array}{l}-0.293 \\
(0.000)\end{array}$ & $\begin{array}{c}0.008 \\
(0.540)\end{array}$ & $\begin{array}{c}0.056 \\
(0.000)\end{array}$ & \\
\hline 12. Innovation & $\begin{array}{c}0.151 \\
(0.000)\end{array}$ & $\begin{array}{c}0.142 \\
(0.000)\end{array}$ & $\begin{array}{c}0.158 \\
(0.000)\end{array}$ & $\begin{array}{c}0.328 \\
(0.000)\end{array}$ & $\begin{array}{c}0.062 \\
(0.000)\end{array}$ & $\begin{array}{c}0.114 \\
(0.000)\end{array}$ & $\begin{array}{c}0.088 \\
(0.000)\end{array}$ & $\begin{array}{l}-0.051 \\
(0.000)\end{array}$ & $\begin{array}{c}0.019 \\
(0.174)\end{array}$ & $\begin{array}{l}-0.035 \\
(0.012)\end{array}$ & $\begin{array}{c}0.053 \\
(0.000)\end{array}$ \\
\hline
\end{tabular}

Notes: $p$-values in parentheses 
Table 6 - Binary Logistic Regressions of Off the Job Managerial Training

\begin{tabular}{|c|c|c|c|c|c|c|c|}
\hline & Model 0 & Model 1 & Model 2 & Model 3 & Model 4 & Model 5 & Model 6 \\
\hline Promotion Focus & & $\begin{array}{c}0.235 \\
(0.000)\end{array}$ & $\begin{array}{c}0.197 \\
(0.000)\end{array}$ & & & $\begin{array}{c}0.234 \\
(0.000)\end{array}$ & $\begin{array}{c}0.195 \\
(0.000)\end{array}$ \\
\hline Prevention Focus & & & & $\begin{array}{c}0.211 \\
(0.090)\end{array}$ & $\begin{array}{c}0.135 \\
(0.511)\end{array}$ & $\begin{array}{c}0.154 \\
(0.217)\end{array}$ & $\begin{array}{c}0.076 \\
(0.714)\end{array}$ \\
\hline \multicolumn{8}{|l|}{ Gain or Loss Experienced (base category no } \\
\hline Turnover Growth) & & & & & & & \\
\hline Negative Turnover Growth & & $\begin{array}{c}-0.033 \\
(0.731)\end{array}$ & $\begin{array}{c}-0.276 \\
(0.271)\end{array}$ & $\begin{array}{c}-0.044 \\
(0.643)\end{array}$ & $\begin{array}{c}-0.030 \\
(0.764)\end{array}$ & $\begin{array}{c}-0.039 \\
(0.685)\end{array}$ & $\begin{array}{l}-0.280 \\
(0.268)\end{array}$ \\
\hline Positive Turnover Growth & & $\begin{array}{c}0.215 \\
(0.002)\end{array}$ & $\begin{array}{c}0.003 \\
(0.988)\end{array}$ & $\begin{array}{c}0.318 \\
(0.000)\end{array}$ & $\begin{array}{c}0.304 \\
(0.000)\end{array}$ & $\begin{array}{c}0.217 \\
(0.002)\end{array}$ & $\begin{array}{l}-0.001 \\
(0.996)\end{array}$ \\
\hline Promotion Focus * Negative Turnover Growth & & & $\begin{array}{c}0.078 \\
(0.290)\end{array}$ & & & & $\begin{array}{c}0.080 \\
(0.283)\end{array}$ \\
\hline Promotion Focus * Positive Turnover Growth & & & $\begin{array}{c}0.064 \\
(0.235)\end{array}$ & & & & $\begin{array}{c}0.062 \\
(0.252)\end{array}$ \\
\hline Prevention Focus * Negative Turnover Growth & & & & & $\begin{array}{c}-0.114 \\
(0.739)\end{array}$ & & $\begin{array}{l}-0.030 \\
(0.931)\end{array}$ \\
\hline Prevention Focus * Positive Turnover Growth & & & & & $\begin{array}{c}0.235 \\
(0.401)\end{array}$ & & $\begin{array}{c}0.210 \\
(0.457)\end{array}$ \\
\hline Employment & $\begin{array}{c}0.512 \\
(0.000)\end{array}$ & $\begin{array}{c}0.444 \\
(0.000)\end{array}$ & $\begin{array}{c}0.445 \\
(0.000)\end{array}$ & $\begin{array}{c}0.499 \\
(0.000)\end{array}$ & $\begin{array}{c}0.500 \\
(0.000)\end{array}$ & $\begin{array}{c}0.447 \\
(0.000)\end{array}$ & $\begin{array}{c}0.448 \\
(0.000)\end{array}$ \\
\hline Female Business & $\begin{array}{c}0.271 \\
(0.001)\end{array}$ & $\begin{array}{c}0.310 \\
(0.000)\end{array}$ & $\begin{array}{c}0.307 \\
(0.000)\end{array}$ & $\begin{array}{c}0.278 \\
(0.001)\end{array}$ & $\begin{array}{c}0.275 \\
(0.001)\end{array}$ & $\begin{array}{c}0.310 \\
(0.000)\end{array}$ & $\begin{array}{c}0.306 \\
(0.000)\end{array}$ \\
\hline Ethnic Business & $\begin{array}{l}-0.716 \\
(0.000)\end{array}$ & $\begin{array}{c}-0.778 \\
(0.000)\end{array}$ & $\begin{array}{c}-0.773 \\
(0.000)\end{array}$ & $\begin{array}{c}-0.693 \\
(0.000)\end{array}$ & $\begin{array}{c}-0.682 \\
(0.000)\end{array}$ & $\begin{array}{c}-0.785 \\
(0.000)\end{array}$ & $\begin{array}{l}-0.772 \\
(0.000)\end{array}$ \\
\hline Firm Age & $\begin{array}{c}-0.049 \\
(0.395)\end{array}$ & $\begin{array}{c}0.042 \\
(0.473)\end{array}$ & $\begin{array}{c}0.041 \\
(0.484)\end{array}$ & $\begin{array}{c}-0.003 \\
(0.965)\end{array}$ & $\begin{array}{c}-0.003 \\
(0.961)\end{array}$ & $\begin{array}{c}0.045 \\
(0.444)\end{array}$ & $\begin{array}{c}0.044 \\
(0.458)\end{array}$ \\
\hline Number of Directors & $\begin{array}{c}0.107 \\
(0.032)\end{array}$ & $\begin{array}{c}0.092 \\
(0.071)\end{array}$ & $\begin{array}{c}0.092 \\
(0.069)\end{array}$ & $\begin{array}{c}0.102 \\
(0.043)\end{array}$ & $\begin{array}{c}0.102 \\
(0.044)\end{array}$ & $\begin{array}{c}0.092 \\
(0.068)\end{array}$ & $\begin{array}{c}0.093 \\
(0.068)\end{array}$ \\
\hline
\end{tabular}

Notes: $p$-values in parentheses; regional controls included in all models; degrees of freedom in squared brackets 
Table 6 - Binary Logistic Regressions of Off the Job Managerial Training continued

\begin{tabular}{|c|c|c|c|c|c|c|c|}
\hline & Model 0 & Model 1 & Model 2 & Model 3 & Model 4 & Model 5 & Model 6 \\
\hline \multicolumn{8}{|c|}{ Innovation (base category no innovation) } \\
\hline In-House Innovation & $\begin{array}{c}0.254 \\
(0.011)\end{array}$ & $\begin{array}{c}0.091 \\
(0.372)\end{array}$ & $\begin{array}{c}0.093 \\
(0.363)\end{array}$ & $\begin{array}{c}0.225 \\
(0.024)\end{array}$ & $\begin{array}{c}0.224 \\
(0.025)\end{array}$ & $\begin{array}{c}0.088 \\
(0.388)\end{array}$ & $\begin{array}{c}0.089 \\
(0.381)\end{array}$ \\
\hline Open Innovation & $\begin{array}{c}0.649 \\
(0.000)\end{array}$ & $\begin{array}{c}0.440 \\
(0.000)\end{array}$ & $\begin{array}{c}0.442 \\
(0.000)\end{array}$ & $\begin{array}{c}0.608 \\
(0.000)\end{array}$ & $\begin{array}{c}0.609 \\
(0.000)\end{array}$ & $\begin{array}{c}0.436 \\
(0.000)\end{array}$ & $\begin{array}{c}0.439 \\
(0.000)\end{array}$ \\
\hline \multicolumn{8}{|c|}{ Industry (base category, retail, accommodation } \\
\hline Primary & $\begin{array}{c}0.323 \\
(0.089)\end{array}$ & $\begin{array}{c}0.330 \\
(0.086)\end{array}$ & $\begin{array}{c}0.333 \\
(0.083)\end{array}$ & $\begin{array}{c}0.364 \\
(0.056)\end{array}$ & $\begin{array}{c}0.362 \\
(0.057)\end{array}$ & $\begin{array}{c}0.328 \\
(0.087)\end{array}$ & $\begin{array}{c}0.330 \\
(0.085)\end{array}$ \\
\hline Manufacturing & $\begin{array}{c}-0.103 \\
(0.356)\end{array}$ & $\begin{array}{l}-0.166 \\
(0.142)\end{array}$ & $\begin{array}{c}-0.173 \\
(0.127)\end{array}$ & $\begin{array}{c}-0.098 \\
(0.379)\end{array}$ & $\begin{array}{l}-0.100 \\
(0.370)\end{array}$ & $\begin{array}{l}-0.165 \\
(0.146)\end{array}$ & $\begin{array}{c}-0.173 \\
(0.128)\end{array}$ \\
\hline Construction & $\begin{array}{c}0.752 \\
(0.000)\end{array}$ & $\begin{array}{c}0.743 \\
(0.000)\end{array}$ & $\begin{array}{c}0.743 \\
(0.000)\end{array}$ & $\begin{array}{c}0.734 \\
(0.000)\end{array}$ & $\begin{array}{c}0.735 \\
(0.000)\end{array}$ & $\begin{array}{c}0.740 \\
(0.000)\end{array}$ & $\begin{array}{c}0.741 \\
(0.000)\end{array}$ \\
\hline Business Services & $\begin{array}{c}0.518 \\
(0.000)\end{array}$ & $\begin{array}{c}0.492 \\
(0.000)\end{array}$ & $\begin{array}{c}0.492 \\
(0.000)\end{array}$ & $\begin{array}{c}0.512 \\
(0.000)\end{array}$ & $\begin{array}{c}0.511 \\
(0.000)\end{array}$ & $\begin{array}{c}0.493 \\
(0.000)\end{array}$ & $\begin{array}{c}0.492 \\
(0.000)\end{array}$ \\
\hline Other Services & $\begin{array}{c}1.124 \\
(0.000)\end{array}$ & $\begin{array}{c}1.172 \\
(0.000)\end{array}$ & $\begin{array}{c}1.172 \\
(0.000)\end{array}$ & $\begin{array}{c}1.152 \\
(0.000)\end{array}$ & $\begin{array}{c}1.153 \\
(0.000)\end{array}$ & $\begin{array}{c}1.171 \\
(0.000)\end{array}$ & $\begin{array}{c}1.172 \\
(0.000)\end{array}$ \\
\hline Constant & $\begin{array}{l}-2.513 \\
(0.000)\end{array}$ & $\begin{array}{l}-3.332 \\
(0.000)\end{array}$ & $\begin{array}{l}-3.212 \\
(0.000)\end{array}$ & $\begin{array}{l}-2.744 \\
(0.000)\end{array}$ & $\begin{array}{l}-2.741 \\
(0.000)\end{array}$ & $\begin{array}{l}-3.349 \\
(0.000)\end{array}$ & $\begin{array}{l}-3.225 \\
(0.000)\end{array}$ \\
\hline$N$ & 5306 & 5306 & 5306 & 5306 & 5306 & 5306 & 5306 \\
\hline$R^{2}$ & 0.231 & 0.253 & 0.253 & 0.237 & 0.237 & 0.253 & 0.254 \\
\hline Hosmer and Lemeshow Test & $\begin{array}{c}6.939 \\
(0.543)\end{array}$ & $\begin{array}{l}10.003 \\
(0.265)\end{array}$ & $\begin{array}{l}12.178 \\
(0.143)\end{array}$ & $\begin{array}{l}18.539 \\
(0.018)\end{array}$ & $\begin{array}{l}15.044 \\
(0.058)\end{array}$ & $\begin{array}{c}9.250 \\
(0.322)\end{array}$ & $\begin{array}{l}10.818 \\
(0.212)\end{array}$ \\
\hline F-test & $\begin{array}{c}1001.3 \\
{[23]} \\
(0.000)\end{array}$ & $\begin{array}{c}1107.6 \\
{[26]} \\
(0.000)\end{array}$ & $\begin{array}{c}1109.5 \\
{[28]} \\
(0.000)\end{array}$ & $\begin{array}{c}1030.9 \\
{[26]} \\
(0.000)\end{array}$ & $\begin{array}{c}1032.3 \\
{[28]} \\
(0.000)\end{array}$ & $\begin{array}{c}1109.1 \\
{[27]} \\
(0.000)\end{array}$ & $\begin{array}{c}1111.8 \\
{[31]} \\
(0.000)\end{array}$ \\
\hline Percentage Correct & 68.3 & 68.7 & 68.9 & 68.7 & 68.6 & 68.6 & 69.0 \\
\hline
\end{tabular}

Notes: $p$-values in parentheses; regional controls included in all models; degrees of freedom in squared brackets 
Table 7 - Binary Logistic Regressions of On the Job Managerial Training

\begin{tabular}{|c|c|c|c|c|c|c|c|}
\hline & Model 0 & Model 1 & Model 2 & Model 3 & Model 4 & Model 5 & Model 6 \\
\hline Promotion Focus & & $\begin{array}{c}0.244 \\
(0.000)\end{array}$ & $\begin{array}{c}0.215 \\
(0.000)\end{array}$ & & & $\begin{array}{c}0.244 \\
(0.000)\end{array}$ & $\begin{array}{c}0.219 \\
(0.000)\end{array}$ \\
\hline Prevention Focus & & & & $\begin{array}{c}0.036 \\
(0.775)\end{array}$ & $\begin{array}{c}-0.235 \\
(0.264)\end{array}$ & $\begin{array}{c}-0.025 \\
(0.842)\end{array}$ & $\begin{array}{l}-0.307 \\
(0.148)\end{array}$ \\
\hline \multicolumn{8}{|l|}{ Gain or Loss Experienced (base category no } \\
\hline Turnover Growth) & & & & & & & \\
\hline Negative Turnover Growth & & $\begin{array}{l}-0.128 \\
(0.185)\end{array}$ & $\begin{array}{c}-0.149 \\
(0.552)\end{array}$ & $\begin{array}{c}-0.131 \\
(0.172)\end{array}$ & $\begin{array}{c}-0.175 \\
(0.081)\end{array}$ & $\begin{array}{c}-0.127 \\
(0.189)\end{array}$ & $\begin{array}{l}-0.191 \\
(0.451)\end{array}$ \\
\hline Positive Turnover Growth & & $\begin{array}{c}0.085 \\
(0.224)\end{array}$ & $\begin{array}{c}-0.156 \\
(0.435)\end{array}$ & $\begin{array}{c}0.193 \\
(0.005)\end{array}$ & $\begin{array}{c}0.171 \\
(0.015)\end{array}$ & $\begin{array}{c}0.085 \\
(0.225)\end{array}$ & $\begin{array}{l}-0.160 \\
(0.422)\end{array}$ \\
\hline Promotion Focus * Negative Turnover Growth & & & $\begin{array}{c}0.007 \\
(0.921)\end{array}$ & & & & $\begin{array}{c}0.004 \\
(0.958)\end{array}$ \\
\hline Promotion Focus * Positive Turnover Growth & & & $\begin{array}{c}0.070 \\
(0.201)\end{array}$ & & & & $\begin{array}{c}0.065 \\
(0.237)\end{array}$ \\
\hline Prevention Focus * Negative Turnover Growth & & & & & $\begin{array}{c}0.550 \\
(0.108)\end{array}$ & & $\begin{array}{c}0.635 \\
(0.063)\end{array}$ \\
\hline Prevention Focus * Positive Turnover Growth & & & & & $\begin{array}{c}0.364 \\
(0.201)\end{array}$ & & $\begin{array}{c}0.341 \\
(0.235)\end{array}$ \\
\hline Employment & $\begin{array}{c}0.515 \\
(0.000)\end{array}$ & $\begin{array}{c}0.450 \\
(0.000)\end{array}$ & $\begin{array}{c}0.450 \\
(0.000)\end{array}$ & $\begin{array}{c}0.504 \\
(0.000)\end{array}$ & $\begin{array}{c}0.504 \\
(0.000)\end{array}$ & $\begin{array}{c}0.450 \\
(0.000)\end{array}$ & $\begin{array}{c}0.450 \\
(0.000)\end{array}$ \\
\hline Female Business & $\begin{array}{c}0.303 \\
(0.000)\end{array}$ & $\begin{array}{c}0.343 \\
(0.000)\end{array}$ & $\begin{array}{c}0.340 \\
(0.000)\end{array}$ & $\begin{array}{c}0.308 \\
(0.000)\end{array}$ & $\begin{array}{c}0.310 \\
(0.000)\end{array}$ & $\begin{array}{c}0.343 \\
(0.000)\end{array}$ & $\begin{array}{c}0.344 \\
(0.000)\end{array}$ \\
\hline Ethnic Business & $\begin{array}{c}-0.293 \\
(0.079)\end{array}$ & $\begin{array}{l}-0.363 \\
(0.031)\end{array}$ & $\begin{array}{c}-0.358 \\
(0.033)\end{array}$ & $\begin{array}{c}-0.270 \\
(0.107)\end{array}$ & $\begin{array}{c}-0.267 \\
(0.111)\end{array}$ & $\begin{array}{c}-0.362 \\
(0.031)\end{array}$ & $\begin{array}{l}-0.358 \\
(0.034)\end{array}$ \\
\hline Firm Age & $\begin{array}{c}-0.044 \\
(0.443)\end{array}$ & $\begin{array}{c}0.034 \\
(0.560)\end{array}$ & $\begin{array}{c}0.034 \\
(0.569)\end{array}$ & $\begin{array}{l}-0.015 \\
(0.804)\end{array}$ & $\begin{array}{c}-0.016 \\
(0.790)\end{array}$ & $\begin{array}{c}0.034 \\
(0.565)\end{array}$ & $\begin{array}{c}0.033 \\
(0.579)\end{array}$ \\
\hline Number of Directors & $\begin{array}{c}0.065 \\
(0.194)\end{array}$ & $\begin{array}{c}0.051 \\
(0.314)\end{array}$ & $\begin{array}{c}0.050 \\
(0.318)\end{array}$ & $\begin{array}{c}0.062 \\
(0.220)\end{array}$ & $\begin{array}{c}0.061 \\
(0.223)\end{array}$ & $\begin{array}{c}0.051 \\
(0.316)\end{array}$ & $\begin{array}{c}0.050 \\
(0.323)\end{array}$ \\
\hline
\end{tabular}

Notes: $\mathrm{p}$-values in parentheses; regional controls included in all models; degrees of freedom in squared brackets 
Table 7 - Binary Logistic Regressions of On the Job Managerial Training continued

\begin{tabular}{|c|c|c|c|c|c|c|c|}
\hline & Model 0 & Model 1 & Model 2 & Model 3 & Model 4 & Model 5 & Model 6 \\
\hline \multicolumn{8}{|c|}{ Innovation (base category no innovation) } \\
\hline In-House Innovation & $\begin{array}{c}0.277 \\
(0.006)\end{array}$ & $\begin{array}{c}0.116 \\
(0.253)\end{array}$ & $\begin{array}{c}0.117 \\
(0.253)\end{array}$ & $\begin{array}{c}0.258 \\
(0.010)\end{array}$ & $\begin{array}{c}0.259 \\
(0.010)\end{array}$ & $\begin{array}{c}0.117 \\
(0.251)\end{array}$ & $\begin{array}{c}0.117 \\
(0.251)\end{array}$ \\
\hline Open Innovation & $\begin{array}{c}0.592 \\
(0.000)\end{array}$ & $\begin{array}{c}0.387 \\
(0.000)\end{array}$ & $\begin{array}{c}0.387 \\
(0.000)\end{array}$ & $\begin{array}{c}0.568 \\
(0.000)\end{array}$ & $\begin{array}{c}0.573 \\
(0.000)\end{array}$ & $\begin{array}{c}0.388 \\
(0.000)\end{array}$ & $\begin{array}{c}0.391 \\
(0.000)\end{array}$ \\
\hline \multicolumn{8}{|c|}{ Industry (base category, retail, accommodation } \\
\hline Primary & $\begin{array}{c}0.454 \\
(0.016)\end{array}$ & $\begin{array}{c}0.454 \\
(0.017)\end{array}$ & $\begin{array}{c}0.458 \\
(0.016)\end{array}$ & $\begin{array}{c}0.491 \\
(0.010)\end{array}$ & $\begin{array}{c}0.494 \\
(0.009)\end{array}$ & $\begin{array}{c}0.455 \\
(0.017)\end{array}$ & $\begin{array}{c}0.460 \\
(0.016)\end{array}$ \\
\hline Manufacturing & $\begin{array}{c}-0.189 \\
(0.096)\end{array}$ & $\begin{array}{l}-0.255 \\
(0.027)\end{array}$ & $\begin{array}{l}-0.257 \\
(0.026)\end{array}$ & $\begin{array}{c}-0.184 \\
(0.107)\end{array}$ & $\begin{array}{l}-0.181 \\
(0.111)\end{array}$ & $\begin{array}{l}-0.255 \\
(0.027)\end{array}$ & $\begin{array}{c}-0.255 \\
(0.027)\end{array}$ \\
\hline Construction & $\begin{array}{c}0.415 \\
(0.002)\end{array}$ & $\begin{array}{c}0.398 \\
(0.003)\end{array}$ & $\begin{array}{c}0.400 \\
(0.003)\end{array}$ & $\begin{array}{c}0.402 \\
(0.002)\end{array}$ & $\begin{array}{c}0.408 \\
(0.002)\end{array}$ & $\begin{array}{c}0.399 \\
(0.003)\end{array}$ & $\begin{array}{c}0.409 \\
(0.002)\end{array}$ \\
\hline Business Services & $\begin{array}{c}0.619 \\
(0.000)\end{array}$ & $\begin{array}{c}0.594 \\
(0.000)\end{array}$ & $\begin{array}{c}0.596 \\
(0.000)\end{array}$ & $\begin{array}{c}0.611 \\
(0.000)\end{array}$ & $\begin{array}{c}0.611 \\
(0.000)\end{array}$ & $\begin{array}{c}0.594 \\
(0.000)\end{array}$ & $\begin{array}{c}0.595 \\
(0.000)\end{array}$ \\
\hline Other Services & $\begin{array}{c}1.137 \\
(0.000)\end{array}$ & $\begin{array}{c}1.173 \\
(0.000)\end{array}$ & $\begin{array}{c}1.176 \\
(0.000)\end{array}$ & $\begin{array}{c}1.154 \\
(0.000)\end{array}$ & $\begin{array}{c}1.154 \\
(0.000)\end{array}$ & $\begin{array}{c}1.173 \\
(0.000)\end{array}$ & $\begin{array}{c}1.176 \\
(0.000)\end{array}$ \\
\hline Constant & $\begin{array}{l}-2.561 \\
(0.000)\end{array}$ & $\begin{array}{l}-3.312 \\
(0.000)\end{array}$ & $\begin{array}{l}-3.218 \\
(0.000)\end{array}$ & $\begin{array}{c}-2.679 \\
(0.000)\end{array}$ & $\begin{array}{l}-2.663 \\
(0.000)\end{array}$ & $\begin{array}{l}-3.309 \\
(0.000)\end{array}$ & $\begin{array}{l}-3.212 \\
(0.000)\end{array}$ \\
\hline$N$ & 5306 & 5306 & 5306 & 5306 & 5306 & 5306 & 5306 \\
\hline$R^{2}$ & 0.230 & 0.250 & 0.251 & 0.233 & 0.233 & 0.250 & 0.251 \\
\hline Hosmer and Lemeshow Test & $\begin{array}{l}10.359 \\
(0.241)\end{array}$ & $\begin{array}{c}9.982 \\
(0.266)\end{array}$ & $\begin{array}{l}10.473 \\
(0.233)\end{array}$ & $\begin{array}{c}8.268 \\
(0.408)\end{array}$ & $\begin{array}{l}13.372 \\
(0.100)\end{array}$ & $\begin{array}{l}10.627 \\
(0.224)\end{array}$ & $\begin{array}{l}12.319 \\
(0.138)\end{array}$ \\
\hline F-test & $\begin{array}{c}992.0 \\
{[23]} \\
(0.000)\end{array}$ & $\begin{array}{c}1090.3 \\
{[26]} \\
(0.000)\end{array}$ & $\begin{array}{c}1092.1 \\
{[28]} \\
(0.000)\end{array}$ & $\begin{array}{c}1006.6 \\
{[26]} \\
(0.000)\end{array}$ & $\begin{array}{c}1009.6 \\
{[28]} \\
(0.000)\end{array}$ & $\begin{array}{c}1090.3 \\
{[27]} \\
(0.000)\end{array}$ & $\begin{array}{c}1095.7 \\
{[31]} \\
(0.000)\end{array}$ \\
\hline Percentage Correct & 68.8 & 69.7 & 69.7 & 69.1 & 69.1 & 69.7 & 69.8 \\
\hline
\end{tabular}


Table 8 - Binary Logistic Regressions of Any Managerial Training

\begin{tabular}{|c|c|c|c|c|c|c|c|}
\hline & Model 0 & Model 1 & Model 2 & Model 3 & Model 4 & Model 5 & Model 6 \\
\hline Promotion Focus & & $\begin{array}{c}0.244 \\
(0.000)\end{array}$ & $\begin{array}{c}0.201 \\
(0.000)\end{array}$ & & & $\begin{array}{c}0.243 \\
(0.000)\end{array}$ & $\begin{array}{c}0.201 \\
(0.000)\end{array}$ \\
\hline Prevention Focus & & & & $\begin{array}{c}0.184 \\
(0.138)\end{array}$ & $\begin{array}{c}0.004 \\
(0.983)\end{array}$ & $\begin{array}{c}0.120 \\
(0.336)\end{array}$ & $\begin{array}{l}-0.060 \\
(0.768)\end{array}$ \\
\hline \multicolumn{8}{|l|}{ Gain or Loss Experienced (base category no } \\
\hline Turnover Growth) & & & & & & & \\
\hline Negative Turnover Growth & & $\begin{array}{l}-0.023 \\
(0.801)\end{array}$ & $\begin{array}{c}-0.338 \\
(0.150)\end{array}$ & $\begin{array}{c}-0.031 \\
(0.734)\end{array}$ & $\begin{array}{c}-0.047 \\
(0.624)\end{array}$ & $\begin{array}{c}-0.028 \\
(0.763)\end{array}$ & $\begin{array}{l}-0.365 \\
(0.124)\end{array}$ \\
\hline Positive Turnover Growth & & $\begin{array}{c}0.149 \\
(0.032)\end{array}$ & $\begin{array}{c}-0.064 \\
(0.732)\end{array}$ & $\begin{array}{c}0.259 \\
(0.000)\end{array}$ & $\begin{array}{c}0.240 \\
(0.001)\end{array}$ & $\begin{array}{c}0.150 \\
(0.031)\end{array}$ & $\begin{array}{l}-0.069 \\
(0.711)\end{array}$ \\
\hline Promotion Focus * Negative Turnover Growth & & & $\begin{array}{c}0.104 \\
(0.142)\end{array}$ & & & & $\begin{array}{c}0.104 \\
(0.145)\end{array}$ \\
\hline Promotion Focus * Positive Turnover Growth & & & $\begin{array}{c}0.067 \\
(0.205)\end{array}$ & & & & $\begin{array}{c}0.063 \\
(0.232)\end{array}$ \\
\hline Prevention Focus * Negative Turnover Growth & & & & & $\begin{array}{c}0.233 \\
(0.485)\end{array}$ & & $\begin{array}{c}0.301 \\
(0.367)\end{array}$ \\
\hline Prevention Focus * Positive Turnover Growth & & & & & $\begin{array}{c}0.314 \\
(0.262)\end{array}$ & & $\begin{array}{c}0.290 \\
(0.303)\end{array}$ \\
\hline Employment & $\begin{array}{c}0.531 \\
(0.000)\end{array}$ & $\begin{array}{c}0.462 \\
(0.000)\end{array}$ & $\begin{array}{c}0.463 \\
(0.000)\end{array}$ & $\begin{array}{c}0.520 \\
(0.000)\end{array}$ & $\begin{array}{c}0.521 \\
(0.000)\end{array}$ & $\begin{array}{c}0.464 \\
(0.000)\end{array}$ & $\begin{array}{c}0.465 \\
(0.000)\end{array}$ \\
\hline Female Business & $\begin{array}{c}0.226 \\
(0.006)\end{array}$ & $\begin{array}{c}0.264 \\
(0.002)\end{array}$ & $\begin{array}{c}0.262 \\
(0.002)\end{array}$ & $\begin{array}{c}0.231 \\
(0.005)\end{array}$ & $\begin{array}{c}0.231 \\
(0.005)\end{array}$ & $\begin{array}{c}0.265 \\
(0.002)\end{array}$ & $\begin{array}{c}0.263 \\
(0.002)\end{array}$ \\
\hline Ethnic Business & $\begin{array}{c}-0.541 \\
(0.001)\end{array}$ & $\begin{array}{l}-0.609 \\
(0.000)\end{array}$ & $\begin{array}{c}-0.604 \\
(0.000)\end{array}$ & $\begin{array}{c}-0.518 \\
(0.002)\end{array}$ & $\begin{array}{l}-0.511 \\
(0.002)\end{array}$ & $\begin{array}{l}-0.615 \\
(0.000)\end{array}$ & $\begin{array}{l}-0.605 \\
(0.000)\end{array}$ \\
\hline Firm Age & $\begin{array}{c}-0.044 \\
(0.436)\end{array}$ & $\begin{array}{c}0.045 \\
(0.436)\end{array}$ & $\begin{array}{c}0.044 \\
(0.449)\end{array}$ & $\begin{array}{l}-0.006 \\
(0.919)\end{array}$ & $\begin{array}{l}-0.007 \\
(0.907)\end{array}$ & $\begin{array}{c}0.047 \\
(0.414)\end{array}$ & $\begin{array}{c}0.046 \\
(0.430)\end{array}$ \\
\hline Number of Directors & $\begin{array}{c}0.052 \\
(0.308)\end{array}$ & $\begin{array}{c}0.037 \\
(0.481)\end{array}$ & $\begin{array}{c}0.037 \\
(0.472)\end{array}$ & $\begin{array}{c}0.048 \\
(0.350)\end{array}$ & $\begin{array}{c}0.048 \\
(0.354)\end{array}$ & $\begin{array}{c}0.037 \\
(0.474)\end{array}$ & $\begin{array}{c}0.038 \\
(0.467)\end{array}$ \\
\hline
\end{tabular}

Notes: $p$-values in parentheses; regional controls included in all models; degrees of freedom in squared brackets 
Table 8 - Binary Logistic Regressions of Any Managerial Training continued

\begin{tabular}{|c|c|c|c|c|c|c|c|}
\hline & Model 0 & Model 1 & Model 2 & Model 3 & Model 4 & Model 5 & Model 6 \\
\hline \multicolumn{8}{|c|}{ Innovation (base category no innovation) } \\
\hline In-House Innovation & $\begin{array}{c}0.274 \\
(0.006)\end{array}$ & $\begin{array}{c}0.107 \\
(0.291)\end{array}$ & $\begin{array}{c}0.109 \\
(0.280)\end{array}$ & $\begin{array}{c}0.250 \\
(0.012)\end{array}$ & $\begin{array}{c}0.250 \\
(0.012)\end{array}$ & $\begin{array}{c}0.104 \\
(0.301)\end{array}$ & $\begin{array}{c}0.106 \\
(0.292)\end{array}$ \\
\hline Open Innovation & $\begin{array}{c}0.673 \\
(0.000)\end{array}$ & $\begin{array}{c}0.459 \\
(0.000)\end{array}$ & $\begin{array}{c}0.462 \\
(0.000)\end{array}$ & $\begin{array}{c}0.639 \\
(0.000)\end{array}$ & $\begin{array}{c}0.642 \\
(0.000)\end{array}$ & $\begin{array}{c}0.456 \\
(0.000)\end{array}$ & $\begin{array}{c}0.462 \\
(0.000)\end{array}$ \\
\hline \multicolumn{8}{|c|}{ Industry (base category, retail, accommodation } \\
\hline Primary & $\begin{array}{c}0.255 \\
(0.164)\end{array}$ & $\begin{array}{c}0.245 \\
(0.186)\end{array}$ & $\begin{array}{c}0.248 \\
(0.181)\end{array}$ & $\begin{array}{c}0.286 \\
(0.120)\end{array}$ & $\begin{array}{c}0.287 \\
(0.119)\end{array}$ & $\begin{array}{c}0.243 \\
(0.190)\end{array}$ & $\begin{array}{c}0.246 \\
(0.185)\end{array}$ \\
\hline Manufacturing & $\begin{array}{c}-0.190 \\
(0.079)\end{array}$ & $\begin{array}{l}-0.257 \\
(0.019)\end{array}$ & $\begin{array}{c}-0.266 \\
(0.016)\end{array}$ & $\begin{array}{l}-0.188 \\
(0.084)\end{array}$ & $\begin{array}{l}-0.187 \\
(0.084)\end{array}$ & $\begin{array}{l}-0.256 \\
(0.020)\end{array}$ & $\begin{array}{c}-0.264 \\
(0.017)\end{array}$ \\
\hline Construction & $\begin{array}{c}0.528 \\
(0.000)\end{array}$ & $\begin{array}{c}0.514 \\
(0.000)\end{array}$ & $\begin{array}{c}0.513 \\
(0.000)\end{array}$ & $\begin{array}{c}0.510 \\
(0.000)\end{array}$ & $\begin{array}{c}0.514 \\
(0.000)\end{array}$ & $\begin{array}{c}0.511 \\
(0.000)\end{array}$ & $\begin{array}{c}0.515 \\
(0.000)\end{array}$ \\
\hline Business Services & $\begin{array}{c}0.544 \\
(0.000)\end{array}$ & $\begin{array}{c}0.520 \\
(0.000)\end{array}$ & $\begin{array}{c}0.519 \\
(0.000)\end{array}$ & $\begin{array}{c}0.539 \\
(0.000)\end{array}$ & $\begin{array}{c}0.538 \\
(0.000)\end{array}$ & $\begin{array}{c}0.521 \\
(0.000)\end{array}$ & $\begin{array}{c}0.519 \\
(0.000)\end{array}$ \\
\hline Other Services & $\begin{array}{c}1.176 \\
(0.000)\end{array}$ & $\begin{array}{c}1.214 \\
(0.000)\end{array}$ & $\begin{array}{c}1.214 \\
(0.000)\end{array}$ & $\begin{array}{c}1.196 \\
(0.000)\end{array}$ & $\begin{array}{c}1.197 \\
(0.000)\end{array}$ & $\begin{array}{c}1.214 \\
(0.000)\end{array}$ & $\begin{array}{c}1.213 \\
(0.000)\end{array}$ \\
\hline Constant & $\begin{array}{l}-2.085 \\
(0.000)\end{array}$ & $\begin{array}{l}-2.884 \\
(0.000)\end{array}$ & $\begin{array}{l}-2.752 \\
(0.000)\end{array}$ & $\begin{array}{l}-2.273 \\
(0.000)\end{array}$ & $\begin{array}{l}-2.262 \\
(0.000)\end{array}$ & $\begin{array}{l}-2.896 \\
(0.000)\end{array}$ & $\begin{array}{l}-2.760 \\
(0.000)\end{array}$ \\
\hline$N$ & 5306 & 5306 & 5306 & 5306 & 5306 & 5306 & 5306 \\
\hline$R^{2}$ & 0.242 & 0.264 & 0.265 & 0.246 & 0.247 & 0.264 & 0.265 \\
\hline Hosmer and Lemeshow Test & $\begin{array}{l}10.583 \\
(0.226)\end{array}$ & $\begin{array}{l}10.809 \\
(0.213)\end{array}$ & $\begin{array}{c}5.902 \\
(0.658)\end{array}$ & $\begin{array}{c}9.252 \\
(0.321)\end{array}$ & $\begin{array}{c}9.103 \\
(0.334)\end{array}$ & $\begin{array}{c}9.666 \\
(0.289)\end{array}$ & $\begin{array}{l}10.623 \\
(0.265)\end{array}$ \\
\hline F-test & $\begin{array}{c}1063.4 \\
{[23]} \\
(0.000)\end{array}$ & $\begin{array}{c}1171.3 \\
{[26]} \\
(0.000)\end{array}$ & $\begin{array}{c}1174.2 \\
{[28]} \\
(0.000)\end{array}$ & $\begin{array}{c}1083.2 \\
{[26]} \\
(0.000)\end{array}$ & $\begin{array}{c}1084.5 \\
{[28]} \\
(0.000)\end{array}$ & $\begin{array}{c}1172.3 \\
{[27]} \\
(0.000)\end{array}$ & $\begin{array}{c}1176.5 \\
{[31]} \\
(0.000)\end{array}$ \\
\hline Percentage Correct & 68.2 & 69.3 & 69.1 & 68.5 & 68.5 & 69.2 & 69.0 \\
\hline
\end{tabular}

Notes: $p$-values in parentheses; regional controls included in all models; degrees of freedom in squared brackets 
Figure 1 - Prospect Theory and Investments in Managerial Human Capital

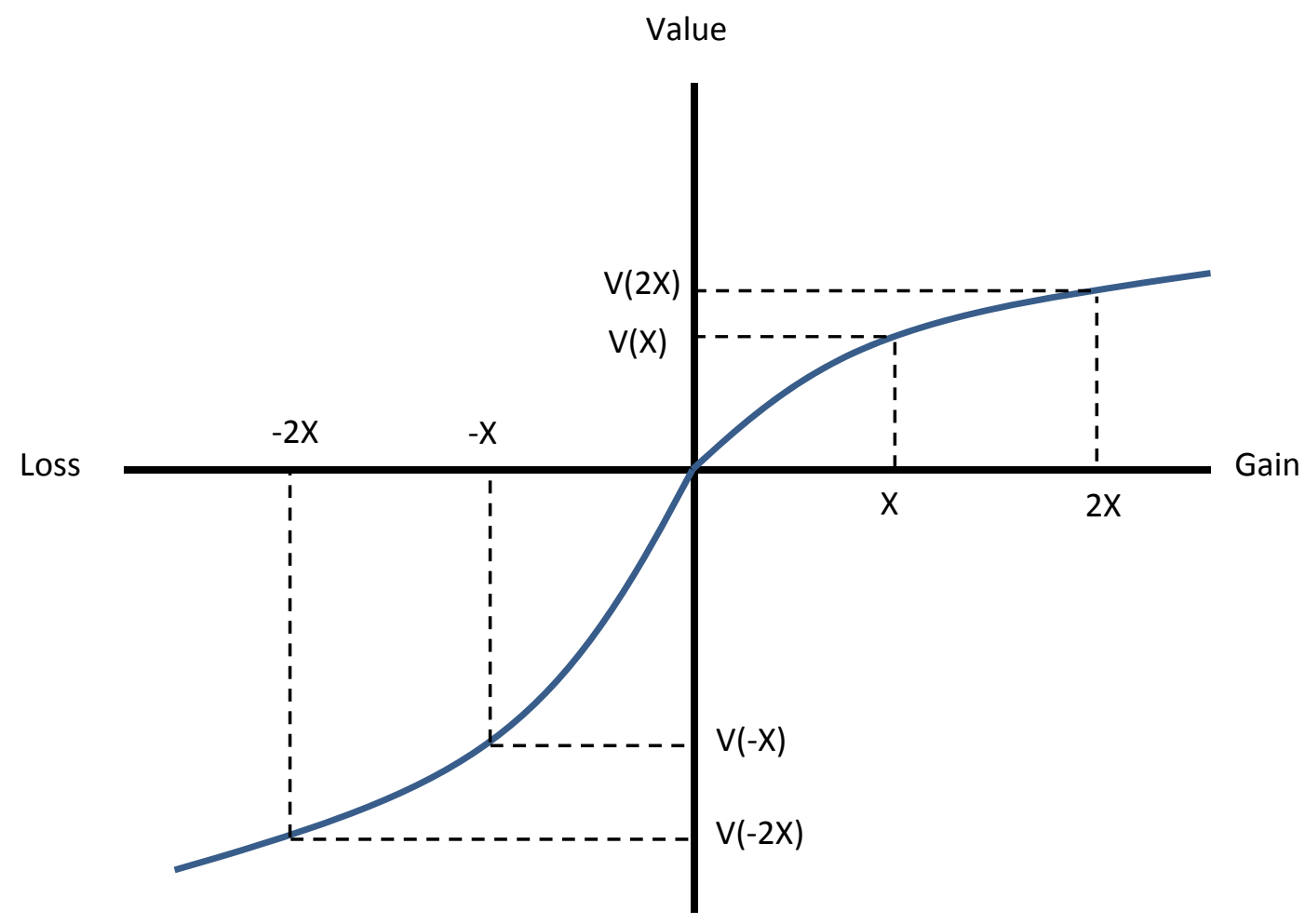


Figure 2 - Proportion Engaging in Off the Job Managerial Training in 2016 by Degree of Promotion Focus and Previous Change in Turnover

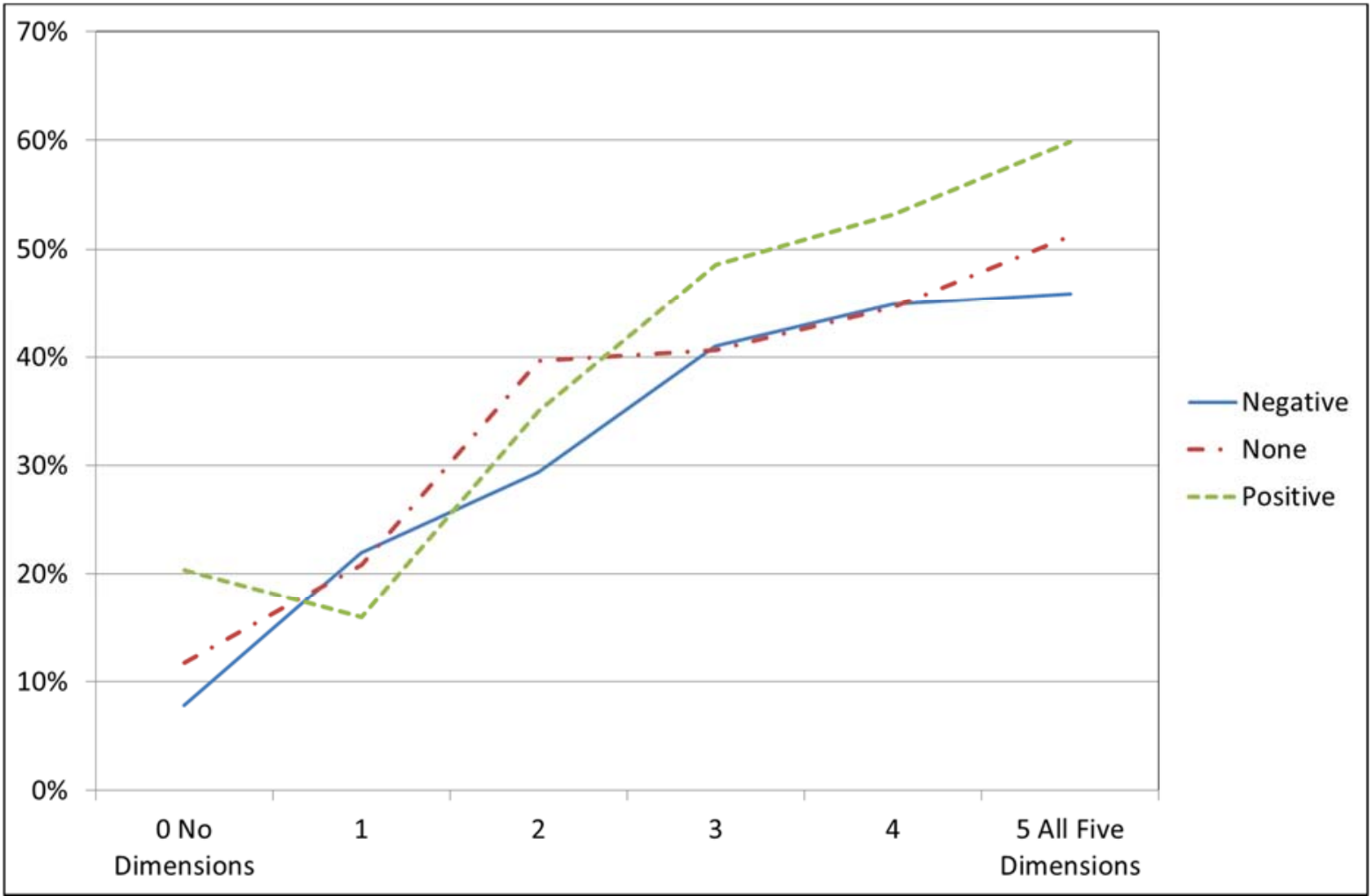

